\title{
A Ironia de Sócrates nos Diálogos de Platão
}

\author{
MATEUS ARAÚJO SILVA \\ Faculdade de Filosofia e Ciências Humanas da UFMG
}

\begin{abstract}
RESUMO: A ironia socrática é tema recorrente tanto nos estudos sobre ironia quanto nos estudos sobre Sócrates. Este trabalho visa averiguar sua incidência desigual nas fontes socráticas mais importantes; discutir sua definição e alguns de seus aspectos, com a ajuda dos comentadores; esboçar e testar um método de análise dos diálogos platônicos aporéticos capaz de, neles, apreendê-la a contento; por fim, apontar seu lugar na atividade filosófica do Sócrates platônico, bem como a especificidade deste ironista em relação a outros.
\end{abstract}

PALAVRAS-CHAVE: Sócrates, Platão, ironia, retórica, método socrático

\section{Introdução: balizamentos preliminares.}

Como é sabido, Sócrates não deixou nenhum escrito para a posteridade. Seus pensamentos, seus ensinamentos e sua atividade nos foram transmitidos através de textos alheios, principalmente de discípulos. Vale dizer, o Sócrates que influenciou profundamente o pensamento ocidental é, em última análise, personagem de outros autores, cujos textos asseguraram sua permanência na tradição. Costuma-se admitir que os textos de Platão, Xenofonte, Aristófanes e Aristóteles constituem as fontes mais importantes de que dispomos para a compreensão da figura de Sócrates ${ }^{1}$. As relações entre os vários Sócrates desenhados pelos textos destes autores e o chamado Sócrates histórico (pensador grego, filho do escultor Sofronisco e da parteira Fenareta, nascido em Atenas por volta de 470/469, e executado pelos atenienses em 399 a.C.) já despertaram muitas controvérsias. Esta questão mobilizou e mobiliza muitos estudiosos ${ }^{2}$, mas não nos propusemos discuti-la aqui.

Neste trabalho, partimos do seguinte dado: não há textos do próprio Sócrates em que pudéssemos examinar a ironia socrática; ela está configurada em textos de outrem nos quais Sócrates tem apenas o estatuto de personagem. Portanto, nesses textos é que devemos buscá-la. Assentado este princípio, circunscrevemos nosso corpus aos textos de Platão, Xenofonte e Aristófanes ${ }^{3}$, e optamos por uma abordagem imanente dos textos escolhidos.

Os perfis de Sócrates desenhados pelos textos de Platão, Aristófanes e Xenofonte diferem muito. Com base na leitura de tais textos, cremos não ser incorreto julgar que a ironia socrática (tal como a definiremos no item 2 infra) aparece com força e nitidez apenas em Platão. De fato, não a encontramos na Apologia de Sócrates, de Xenofonte. Nos Memoráveis e no Banquete, do mesmo autor, ela aparece muito pouco, e ainda sem muita força ${ }^{4}$. Na comédia As Nuvens, de Aristófanes, Sócrates aparece não como ironista (sujeito da ironia) mas como ironizado (vítima 
dela) ${ }^{5}$. Ao contrário, em vários diálogos de Platão (embora não em todos e talvez nem mesmo na maioria deles) a ironia socrática aparece forte e nítida, em todo o seu esplendor.

Assim, a análise dos diálogos platônicos, no que tange à ironia socrática, nos pareceu mais proveitosa do que a dos textos de Xenofonte ou Aristófanes. Donde o privilégio dado em nosso trabalho aos diálogos platônicos, dentre os quais o Hipias Maior e o Hípias Menor foram examinados mais de perto. Antes de abordá-los, tentemos definir o que estamos chamando de ironia socrática em nosso texto, e vejamos o que os comentadores de Sócrates têm a dizer sobre ela.

\section{Definição genérica de ironia socrática.}

Encontrar uma definição estrita e positiva da ironia socrática que, a um tempo, recubra suas diversas manifestações no comportamento de Sócrates ao longo dos diálogos platônicos e aproveite os dados trazidos pelas abordagens dos diversos comentadores de Sócrates, não nos parece tarefa fácil ${ }^{6}$. Para realizá-la, escolhemos, entre outros possíveis, o seguinte caminho: partindo de uma definição genérica da ironia socrática, tentaremos enriquecê-la com a apresentação esquemática e a discussão de alguns de seus aspectos apontados pelos comentadores. Tal discussão tentará dar suporte a um método de análise da ironia socrática nos diálogos, que proporemos a seguir, e testaremos diante dos dois Hipias. Estas análises particulares nos fornecerão elementos para redefinirmos a ironia socrática na conclusão do nosso percurso.

Num nível mais geral, podemos definir a ironia socrática, tal como aparece nos diálogos platônicos, como um modo de proceder da personagem Sócrates nas conversas com seus interlocutores ${ }^{7}$. Tal modo de proceder de Sócrates consistiria basicamente em falar algo diferente daquilo que pensava, usando a simulação, seja para desmerecer a si mesmo, seja para elevar os interlocutores que ele queria refutar. Esta definição, tributária de Cícero ${ }^{8}$, nos parece, entre as várias com as quais nos deparamos; a mais compreensiva e operatória, abrangendo manifestações freqüentes nos diálogos mas que não caberiam em definições mais restritivas ${ }^{9}$. Além disso, ela traz em seu núcleo a idéia de desacordo entre fala e pensamento como central à ironia socrática, idéia esta que boa parte dos comentadores a que tivemos acesso defende, implícita ou explicitamente. Tentaremos apontar, mais adiante, problemas nesta idéia e sugerir sua substituição por outra (desacordo entre fala e situação) em que nossa análise dos diálogos se apoiará. A crítica e o aprimoramento da definição inicial ajudarão a esclarecer nossa perspectiva e os motivos que nos levaram a adotá-la.

\section{Aspectos da ironia socrática apontados pelos comentadores}

Dada e justificada a definição genérica de ironia socrática, vejamos brevemente em que medida os comentadores de Sócrates nos ajudam a enriquecê-la. Tentaremos extrair de seus textos o que nos ajude a apontar os aspectos metodológico, retórico e literário da ironia socrática. Vale lembrar que a perspectiva, a intenção e as posições de cada comentador ao tratar da ironia socrática diferem consideravelmente. Além disso, nem sempre eles estão falando do mesmo Sócrates (uns se referem ao Sócrates platônico, outros ao histórico, alguns ainda ao xenofôntico). No entanto, numa apresentação deliberadamente esquemática como a que esboçaremos aqui, cremos ser possível enfatizar mais aquilo que os aproxima do que aquilo que os distancia, examinando-os em conjunto e agrupando-os de acordo com orientações gerais. Do contrário, o esquema seria inviável.

Os comentadores de Sócrates lidos por nós são praticamente unânimes ao destacarem o 
aspecto metodológico/filosófico da ironia socrática. Em que pesem as diferenças, os acentos e as nuances de interpretação, quase todos eles encaram a ironia socrática como procedimento metodológico, e tratam dela no contexto da discussão sobre o método filosófico socrático. A relação entre ironia e método filosófico ora é entendida como conexão estreita ou pertencimento, ora como identidade pura e simples (ironia $=$ método). Nos dois casos, a ironia é vinculada ou identificada ora com o método como um todo, ora com algum de seus momentos constitutivos (refutação, indução, maiêutica). Prevalece uma compreensão da ironia como momento inicial do método, pars destruens, que prepararia o caminho para os momentos mais construtivos.

Como quase todos os comentadores enfatizam o vínculo estreito entre ironia socrática e método (como um todo, ou num de seus momentos constitutivos), limito-me a mencionar a este respeito Zeller (1955, p.127), Schaerer (1938, p.55) e Reale \& Antiseri (1990, p.97-98). Entre aqueles que, em algumas passagens, parecem identificar ironia e método, cito Mondolfo (1971, p.163-68), Châtelet (1981, p.80 e 82) e Manon (1992, p.24) ${ }^{10}$. Entre os que tendem a identificar ironia e refutação, cada um a seu modo, lembro Hegel (1955, p.52-56), Brun (1984, p.117-18 e 126), F. Adorno (1990, p.75-76) e de novo Manon (1992, p.26-27)" . Há quem identifique de alguma forma ironia e indução, como o próprio Châtelet numa passagem (1981, p.82). Émile Boutroux considera a ironia um elemento constituinte da forma exterior do método socrático, forma que se distinguiria do fundo lógico do método. A forma exterior incluiria a ironia, a maiêutica, o domínio de si e o amor (Eros). O fundo lógico seria constituído pela definição e pela indução (1897, p.46 e ss.).

Procuremos agora apontar, ainda que de modo sumário, o aspecto retórico da ironia socrática ${ }^{12}$. Se entendermos a retórica, com Heinrich Lausberg, como "um sistema mais ou menos bem elaborado de formas de pensamento e de linguagem, as quais podem servir à finalidade de quem discursa para obter, em determinada situação, o efeito que pretende" (1982, p.75), perceberemos a ironia socrática como um procedimento retórico. Afinal, ela contribui, ao lado de outras formas, para a obtenção do efeito pretendido por Sócrates em seu discurso (discutiremos tal efeito pretendido no item 7 infra).

Do mesmo modo, se concebermos, na trilha de Jean Laborderie (1978, p. 11-68) e outros, os diálogos platônicos como um gênero literário original (com genealogia, leis e características próprias) que teria servido de meio de expressão para a filosofia platônica ${ }^{13}$, não será difícil admitir também o caráter literário da ironia socrática. Vista por este ângulo, ela nunca deixa de ser um dos elementos propriamente literários de que se vale Platão na elaboração dos diálogos.

Estes três aspectos, de certo modo, fornecerão o eixo para nossa abordagem da ironia do Sócrates platônico. Antes de discutirmos os aspectos literário e retórico dessa ironia, tentaremos mostrar que nos Diálogos ela não se reduz ao método socrático. Se neles ela potencializa a eficácia da refutação, da maiêutica, da indução e da definição, ela no entanto não parece ser necessária ao método socrático. Este parece perfeitamente pensável e possível sem a companhia da ironia ${ }^{14}$. Lembremos aqui os diálogos Cármides, Lísis e Filebo, nos quais os procedimentos metodológicos mencionados têm uma presença marcante, não se fazendo porém acompanhar de ironia $^{15}$.

A constatação da ausência de ironia onde o método se exercita com vigor já dificultaria a identificação dos dois. Mas a esta constatação seria preciso acrescentar ainda um modelo de análise capaz de distinguir ironia e método socráticos nos diálogos em que os dois estão fortes, e aparentemente conjugados. Tentaremos fazer isto no exame do Hípias Maior e do Hípias Menor.

Em nossa análise, substituiremos também a concepção da ironia como desacordo entre fala e pensamento pela concepção da ironia como desacordo entre fala e situação. Esta concepção nos parece mais operatória que aquela, como podemos demonstrar recorrendo a uma questão concreta: a confissão socrática de ignorância ${ }^{16}$. Haveria outras, mas o exame desta questão 
permite ver com clareza as vantagens da substituição referida ${ }^{17}$. Com efeito, a confissão socrática de ignorância mobilizou um bom número de comentadores e toda a discussão em torno dela se baseou na concepção da ironia como desacordo entre a fala e o pensamento de Sócrates.

Um grupo de comentadores, com diferença de nuances, tende a minimizar a presença da ironia ou, no limite, negá-la na confissão socrática de ignorância, porque esta seria sincera e verdadeira (Sócrates estaria realmente convicto de não saber) ${ }^{18}$. Simeterre (1948, p.51), Koyré (1988, p.12) e Mondolfo (1971, p.167), ao contrário, julgam que Sócrates simula ignorância, e portanto ironiza, quando diz nada saber. Gómez-Lobo (1993) nega a ironia em certas declarações socráticas de ignorância (1993, p.193-195 e 199-202), mas aponta sua presença em outras, relacionađáas ao âmbito da ética (1993, p.195-198). Por sua vez, Kierkegaard (1991, p.233), Manon (1992, p.29-30) e Vlastos (1987, p.86 e 92), cada qual com sua justificativa, consideram a confissão de ignorância a um só tempo irônica e autêntica. Irônica porque o não saber de Sócrates encerraria muito mais saber do que um não saber qualquer (funcionaria como um início do saber, ou em alguns casos como uma crença verdadeira justificada); autêntica porque Sócrates não teria realizado em si mesmo a idéia do saber (no sentido de conhecimento acompanhado de certeza, precisa Vlastos).

Mais do que discutir quem tem razão aqui, importa perceber em que medida praticamente todos, afirmando ou negando a ironia, o fazem a partir de um mesmo esquema, no qual trata-se sempre de relacionar fala e pensamento de Sócrates. Em alguns casos a discussão é genérica e não se debruça sobre uma fala concreta de Sócrates em algum texto. Nos melhores casos, falas concretas estão sendo examinadas. Ora, nesses casos os dois termos da relação (fala e pensamento) não parecem estar no mesmo plano: as falas em que Sócrates se diz ignorante são concretas, particulares e localizadas, ao passo que o pensamento de fundo, sobre o qual a fala acaba sendo rebatida, é geral e independe daquela situação concreta em que a fala foi proferida. É como se tal pensamento pairasse sobre todo e qualquer comportamento verbal concreto do personagem Sócrates nos textos ${ }^{19}$.

O desequilíbrio é flagrante: o aqui-agora das falas de Sócrates neste ou naquele texto é rebatido sobre um fundo fixo e menos circunstanciado. Ora, o comentador só pôde reconstruir este fundo (a saber, a imagem que Sócrates teria de si mesmo) indiretamente, através das várias imagens de Sócrates de que dispunha, do cotejo entre elas etc. Quando se enfoca um diálogo platônico a partir desta equação, o fundo permanece mais dependente e comprometido com o Sócrates histórico (com sua reconstituição possível, bem entendido) do que as falas concretas do personagem Sócrates circunscritas ao texto do diálogo.

Dessa maneira, uma imagem construída fora do diálogo (imagem daquele Sócrates que estaria realmente convicto de não saber) acaba moldando a compreensão da significação intrínseca de passagens do diálogo. Tal esquema interpretativo parece problemático, pois tende a negligenciar o contexto discursivo (isto é, as circunstâncias internas a cada diálogo platônico) do qual as falas de Sócrates são extraídas, alterando assim o sentido dessas falas e prejudicando sua compreensão.

\section{Análise da ironia socrática nos diálogos platônicos aporéticos.}

Os problemas do esquema de análise acima criticado talvez fortaleçam o crédito de algum outro método que os evite. Neste trabalho tentamos esboçar um, sem perder de vista o que Oswald Ducrot chamou de "situação de discurso", a saber: "o conjunto das circunstâncias no meio das quais se desenrola um acto de enunciação (oral ou escrito). Deve-se entender por isto, ao mesmo tempo, o ambiente físico e social em que se realiza este acto, a imagem que dele têm os 
interlocutores, a identidade destes, a idéia que cada um tem do outro (incluindo a representação que cada um tem do que o outro pensa dele), os acontecimentos que precederam o acto de enunciação (sobretudo as relações que antes tiveram os interlocutores, e sobretudo as trocas de palavras em que se insere a enunciação em questão)" (Ducrot, 1982, p.391).

Neste conjunto de circunstâncias referidas por Ducrot, nossa ênfase foi posta naquelas internas ao diálogo. Ou seja, em nosso método de análise a situação de discurso das falas de Sócrates tende a não ultrapassar o contexto lingüístico dos diálogos platônicos. Cabe lembrar que a importância, para a apreensão da ironia, do contexto (que restringimos aqui, por necessidades nossas, ao contexto lingüístico) é freqüentemente salientada nos estudos sobre a ironia ${ }^{20}$.

Assim, para apreender as ocorrências da ironia socrática e seu sentido nos diálogos platônicos aporéticos ${ }^{21}$, em particular no Hípias Maior e no Hípias Menor, o método de análise que esboçamos começa por distinguir duas dimensões do diálogo, ambas configuradas nas falas dos personagens: 1) uma dimensão propriamente argumentativa, na qual os interlocutores discutem e tentam resolver as questões surgidas na conversa; 2) uma dimensão que podemos chamar de valorativa ou judicativa, comportando as falas que trazem juízos de valor de cada interlocutor não sobre os argumentos e as questões discutidas, mas sobre si mesmo e sobre o outro.

A ironia se localizaria no desacordo entre as dimensões argumentativa e judicativa ou, mais precisamente, entre a situação ou contexto argumentativo e as falas judicativas de Sócrates. Vale dizer, os juízos de valor de Sócrates, tomados individualmente, devem ser interpretados a partir de sua relação com o contexto argumentativo em que eles surgem. Neste método de análise, as duas dimensões apontadas são internas ao diálogo e às suas circunstâncias, não havendo necessidade de apelo ou remissão a algo externo ao diálogo para atingir suas significações intrínsecas; além disso, uma vez aceito este método, a ironia socrática não mais será vista como mero instrumento do método socrático, diminuindo assim o risco de perdermos a especificidade dela. Ou, dito nos termos de nossa análise, a ironia socrática não se localizará mais na dimensão argumentativa do diálogo (na qual localizamos todos os procedimentos metodológicos socráticos, tais como a refutação, a indução, a maiêutica, a definição), mas na relação de desacordo entre as duas dimensões, como procuraremos mostrar no exame dos dois Hípias.

Apresentado o método de análise, testemo-lo examinando como, no curso do Hípias Menor, os elogios reiterados de Sócrates a Hípias e a modéstia socrática vão assumindo um tom cada vez mais irônico, à medida em que aumentam o embaraço e as dificuldades de Hípias na argumentação ${ }^{22}$. A localização da ironia socrática no desacordo entre as dimensões argumentativa e judicativa do diálogo nos permitirá separar, na análise, ironia socrática de método socrático, ali mesmo onde os dois aparecem mais fortemente conjugados. Tentaremos seguir de perto o percurso do diálogo, e estaremos citando a tradução para o português de Carlos Alberto Nunes. Nas passagens citadas do Hípias Menor, como nas do Hípias Maior mais adiante, as falas de Sócrates estarão antecedidas pela letra "S" e as de Hípias pela "H".

\section{A ironia socrática no Hípias Menor.}

Contendo basicamente falas de Sócrates e do famoso sofista que lhe empresta o nome, este diálogo pertence ao grupo daqueles em que a modéstia socrática encontra pela frente a jactância de um interlocutor renomado e respeitado por todos, e que por isso se julga mais sábio do que $e^{23}$. Estes interlocutores jactanciosos tendem a ser, nos diálogos platônicos, os alvos preferenciais e mais freqüentes da ironia de Sócrates. Dentre todos, Hípias se destaca, merecendo o título de campeão da jactância nos diálogos platônicos. Isto faz do Hípias Menor um diálogo digno de nossa análise. Com efeito, no Hipias Menor percebemos um contraste gritante entre a 
postura de Hípias, que julga saber tudo, e a de Sócrates, que diz nada saber. Tal contraste, como veremos, é um campo propício para as manifestações da ironia socrática ${ }^{24}$.

O diálogo começa imediatamente depois da "magnífica exibição de Hípias" (palavras de Éudico, em 363a), numa conferência sobre Homero saudada com um coro de elogios por uma audiência grande. Finda a declamação pública, permanecem no local apenas Hípias, Sócrates e Éudico, que exorta Sócrates a se manifestar sobre o que ouvira. Daí em diante, Sócrates e Hípias travarão uma conversa que, partindo da fala de Hípias sobre os personagens homéricos Odisseu e Aquiles, desembocará na seguinte questão: pode o mal ser cometido voluntariamente?

Sócrates demonstrará o absurdo a que a resposta afirmativa conduz. No percurso do diálogo, as respostas de Hípias levam a impasses explicitados por Sócrates. Este, ao não aceitar e mostrar os problemas das respostas de Hípias, levará o sofista a se impacientar. O diálogo termina sem solução para a questão discutida. Em sua dimensão argumentativa, que resumimos nas frases anteriores mas não pretendemos enfatizar daqui para frente, o percurso do diálogo descreve portanto o movimento de uma refutação - a refutação socrática a Hípias ${ }^{25}$. A ironia socrática poderia ser aferida no desacordo progressivo entre os juízos de valor emitidos por Sócrates no curso do diálogo (elogios a Hípias e desvalorizações de si) e o contexto argumentativo em que eles aparecem, cada vez mais desfavorável a Hípias.

Traçado o esquema geral de nossa análise e apresentada, ainda que sumariamente, a dimensão argumentativa do diálogo, concentremo-nos agora nos juízos de valor emitidos por Sócrates ao longo do diálogo, seguindo seu curso. Logo no início, fica muito clara a oposição entre a modéstia de Sócrates e a jactância de Hípias. Alternam-se neste momento falas jactanciosas de Hípias e falas de Sócrates em que ele se subestima ou elogia seu interlocutor:

"S - Como és feliz, Hípias, se puderes, realmente, em todas as olimpíadas ingressar no santuário tão seguro de ti mesmo e confiante em tua sabedoria! Surpreender-me-ia se algum dos atletas das competições de força física ali se apresentasse para lutar, sem medo e tão confiante no seu próprio corpo como tu dizes estar com relação à tua inteligência.

H - É natural, Sócrates, o que se dá comigo. Desde que comecei a tomar parte nos jogos olímpicos, não encontrei ninguém superior a mim, seja no que for.

S - Que belo monumento de sabedoria, Hípias, deve ser tua glória, para a cidade de Elide e para teus genitores!" (364a-b).

Vejamos ainda um trecho um pouco adiante:

"H - De muito bom grado, Sócrates, vou expor-te com maior clareza do que antes [...].

S - Ora, ora Hípias! Só te peço que me faças o favor de não zombar de mim no caso de eu custar a apanhar o sentido do que dizes e de amiudar minhas perguntas. [...].

H - Fôra vergonhoso, Sócrates, ensinando eu, como ensino, justamente isso a outras pessoas, e fazendo-me pagar pelo meu trabalho, não mostrar condescendência quando me interrogas, nem responder-te com bons modos.

S - Belas palavras!" (365c-d).

Note-se como o diálogo começa com os papéis claramente definidos. Hípias no lugar do sábio que, em tom professoral, ensinará indulgentemente o modesto - mas interessado - Sócrates. Neste início, as falas que produzem tal distribuição de papéis ainda não parecem conflitar com a situação (que serve a elas de contexto) dos interlocutores no debate. Porém, no desenrolar do diálogo o progressivo embaraço de Hípias nos forçará a interpretar as falas elogiosas ou modes- 
tas de Sócrates como irônicas. O movimento do diálogo vai aumentando progressivamente a incongruência entre, de um lado, o comportamento modesto ou elogioso de Sócrates para com Hípias e, de outro, a situação cada vez mais embaraçosa de Hípias na discussão.

Percebemos isso num momento posterior do diálogo, em que Sócrates já é o responsável pelo encaminhamento da discussão, direcionando suas perguntas e, de certo modo, as respostas de Hípias, em função de seu próprio raciocínio. Neste momento, Hípias ainda não está diante de embaraços evidentes (não se contradisse ainda, nem foi obrigado a conceder a Sócrates conclusões com as quais não concorda). Porém, já se vê numa situação relativamente desconfortável, preso a um encaminhamento da discussão que interessa a Sócrates mas não a ele.

Depois de firmados alguns pontos da discussão, Sócrates vai buscar exemplos exatamente nas artes em que Hípias é considerado o melhor. Voltam então a aparecer as características de cada interlocutor já apontadas por nós: a jactância de Hípias e a postura exageradamente elogiosa de Sócrates. Notamos, porém, que, ao serem reiterados, os elogios de Sócrates adquirem um sentido novo e soam suspeitos, pois os papéis que eles reforçavam no início do diálogo (Hípias como o sábio, Sócrates como o modesto) já não combinam com o desempenho argumentativo de seus atores. As expectativas criadas pela distribuição inicial dos papéis não se cumpriram, e eles perderam credibilidade. Afinal, a esta altura do diálogo, é Sócrates quem parece conduzir a conversa, com engenho e mais desenvoltura que Hípias. Como imaginá-lo tão inferior e distante da sabedoria de Hípias, se vemos seu desempenho tão melhor que o do sofista, numa conversa travada em igualdade de condições? No festival de elogios que motivaram estes comentários, destaquemos alguns:

“S - [...] És hábil em cálculo e em aritmética?

H - Muito, Sócrates" (366c).

“ S - Mas, és apenas o mais capaz e mais sábio, ou também o melhor na matéria em que é capaz e sábio, isto é, em aritmética?

H - Sim, também o melhor, Sócrates.

S - Desse modo, serias o mais capaz de dizer a verdade sobre essa matéria, não é assim?

$\mathrm{H}$ - Decerto.

S - E quanto a enganar a respeito do mesmo assunto? Responde-me como até aqui tens feito, Hípias, com igual nobreza e magnificência. [...]. Tu, por seres sábio, se quisesses, mentirias sempre bem?

H - Sim, nesse ponto tens toda a razão.[...]

S - [...] Pois, de acordo com o que disseste, se ainda estás lembrado, quem é incapaz de mentir nunca poderá mentir.

H - Sim, estou lembrado; disse isso mesmo" (366d-367b, grifo nosso)

Aqui aparece o embaraçoso refrão de Sócrates ("se ainda estás lembrado"), espécie de preâmbulo, frequiente, da refutação socrática nos diálogos platônicos. Tal refrão socrático anuncia o perigo iminente de contradição no discurso do seu interlocutor. Ao ouvi-lo, o interlocutor começa a antever a necessidade de defender uma parte de seu discurso de outra parte que parece contradizê-la. Depois do refrão, Sócrates retomará os exemplos, mencionando artes em que Hípias se julga o mais sábio (geometria, astronomia). O elogio a Hípias, imbricado com a argumentação de Sócrates, se intensificará:

“S - Vamos, Hípias, examina sob esse aspecto outras ciências, para veres se não se 
dá a mesma coisa em todas elas. Pois és o mais sábio dos homens em todas as artes, como de uma feita já te ouvi gabar-te na ágora, junto de uma banca de câmbio, ao enumerares a variedade verdadeiramente invejável de tuas aptidões. [...]. A respeito das ciências a que a momentos me referi, apresentavas-te como superior a quem quer que fosse, bem como em ritmo, em harmonia e na arte de bem escrever, e em muitos outros gêneros, se bem me lembro, em que também te sobressaías. Sim, quase ia esquecendo a sua mnemotécnica, em que te consideras particularmente brilhante. É certeza haver-me olvidado de muita coisa. Mas , como disse, considera não só em relação às suas artes - e são tantas! - como também às demais, e dize-me se, de conformidade com o que assentamos até agora, eu e tu, encontras alguma em que não seja a mesma pessoa, porém pessoas diferentes, a que fala a verdade e a que mente" (368a$\mathrm{e}$, grifos nossos).

Esta passagem nos mostra uma incongruência entre os juízos de valor emitidos por Sócrates e a situação argumentativa em que eles aparecem: Sócrates elogia Hípias de modo exagerado justamente num momento em que parece iminente sua refutação ao sofista. Além disso, seus elogios parecem conter sinais de ironia. Sirva de exemplo a insistência com que Sócrates reproduz, em seus elogios, as declarações de Hípias sobre sua própria excelência. É como se insinuasse: "Deves ser mesmo extraordinário, Hípias, pois não paras de repetir isto", pondo em questão a veracidade dos auto-elogios de Hípias. Lendo o trecho, podemos sentir que Sócrates, neste momento do diálogo, trata Hípias como um jactancioso.

O recurso à farta exemplificação (os exemplos sendo buscados justamente nas muitas artes de Hípias) permite a Sócrates concluir algo desconcertante e contrário às afirmativas de Hípias sobre Odisseu e Aquiles. Encurralado, Hípias "apela", perde a compostura pela primeira vez no diálogo, ataca Sócrates e parte para o desafio:

“H - Ó Sócrates, tu sempre teces sutilezas desse tipo, separando do discurso o que nele se contém de mais abstruso; apegas-te a essa particularidade e te comprazes com minúcias, sem nunca apanhares em conjunto o tema em discussão. Agora mesmo, caso queiras, posso demonstrar-te com abundância de exemplos e em forma elegante que Homero apresentou Aquiles em seu poema como pessoa sem malícia e superior a Odisseu, enquanto este é doloso, fértil em mentiras e inferior a Aquiles. Se quiseres provar que Odisseu é superior a Aquiles, opõe outro discurso ao meu. Assim os circunstantes poderão julgar qual de nós dois fala melhor.

S - Ó Hípias, eu não contesto absolutamente que não sejas mais sábio do que eu. Mas sempre tive por hábito prestar atenção à exposição de quem quer que seja, principalmente quando o orador se me afigura sábio. O desejo de aprender me leva a interrogá-lo de vários modos, a examinar o que ele diz e a refletir sobre suas palavras, para melhor compreendê-las. Mas se o orador me parece insignificante, não só não lhe formulo perguntas de nenhuma espécie, como não presto atenção ao que ele fala. Por aí, justamente, é que podes conhecer quem eu tenho na conta de sábio. Hás-de encontrar-me, então, atento às suas palavras e empenhado em fazer-lhe perguntas, para instruir-me e tirar proveito delas" (369b-e).

Situada na metade do diálogo, esta passagem traz um dado novo: ao reagir e explicitar seu desagrado com a postura de Sócrates, Hípias mostra ter detectado ironia no comportamento de seu interlocutor. A partir de agora, não haverá mais lugar para boa-fé no diálogo, que prosseguirá com pequenas provocações mútuas, até Sócrates perceber na fala de Hípias uma contradição, e denunciá-la num trecho memorável: 
“ S - Vês, Hípias, como tenho razão de dizer que sou tenaz quando me ponho a interrogar os sábios? Pode bem dar-se que seja esse o meu único merecimento; de tudo o mais sou muito parcamente dotado, pois sempre me escapa o sentido íntimo das coisas, continuando eu sem saber nada. A melhor prova disso está no fato de, sempre que me ponho a conversar com alguma pessoa de reconhecido mérito e de cuja sabedoria os helenos dão testemunho, tornar-se manifesto que eu nada sei. Não há questão, por assim dizer, em que estejamos de acordo. E que maior prova de ignorância poderá haver do que discordarmos dos sábios? [...] É o que se dá agora conosco, pois não posso concordar com o que dizes; discordo em toda a linha. [...]. A mim parece, meu caro Hípias, precisamente o oposto do que dizes. [...]. Usa, portanto, de condescendência para comigo e não te recuses a curar-me a alma. Muito maior benefício me prestarás livrando minha alma de sua ignorância do que se me curasses de uma doença do corpo" (372a-373a).

Hípias, uma fala antes desta, não aceitara que os mentirosos voluntários são melhores que os involuntários. Mas Sócrates alegou que esta tinha de ser a conclusão necessária da posição do sofista até aquele momento. Ora, a argumentação socrática poderia perfeitamente prescindir dos torneios irônicos que reproduzimos acima. Sócrates poderia simplesmente confrontar a recusa de Hípias em aceitar a conclusão (os mentirosos voluntários são melhores que os involuntários) com a linha de argumentação do próprio sofista que conduziria àquela conclusão. No entanto, Sócrates não dispensa a ironia em sua refutação a Hípias. Pelo contrário, volta a elogiar o sofista chamando-o de sábio e volta a se dizer ignorante. Neste caso, vemos que Sócrates não está ironizando por exigência do seu método, mas por motivos de outra ordem. Passagens como esta nos autorizam a sustentar que há na ironia socrática algo irredutível ao método socrático. Afinal, aquela não pode ser circunscrita, como este, ao terreno da argumentação.

Sócrates ainda acrescenta que se Hípias não se dispuser a "curá-lo" com frases curtas, a cura será impossível. Éudico intervêm para que Hípias não abandone a discussão. Hípias aceita ficar, mas diz que "Sócrates perturba sempre a exposição dos outros, dando a impressão, até, de que é desonesto" (373b). A esta segunda perda de compostura, Sócrates responde ironizando abertamente:

“ S - Ó meu caro Hípias! Não faço isso por querer. Se fosse o caso, eu seria sábio e astucioso, de acordo com o que disseste. Por isso, deves ser condescendente comigo; tu mesmo declaraste que devemos ser indulgentes com as pessoas que praticam involuntariamente o mal" (373b).

Nesse momento, Sócrates parece estar se divertindo ao incorporar em sua fala, com intenção irônica, pontos da argumentação de Hípias ${ }^{26}$. O diálogo prosseguirá sem muita ironia até chegar ao final aporético. A irresolução dos impasses e paradoxos, a que a posição de Hípias conduziu, serviu para refutá-la. Apesar da refutação, Sócrates fecha o diálogo renovando a desvalorização de si e o elogio a Hípias. No desacordo entre a situação e os juízos de Sócrates, sentimos a ironia:

"S - Como te dizia há pouco, nesses assuntos eu vivo sempre a oscilar de um lado para o outro, sem deter-me nunca numa opinião segura. Não é de admirar, porém, que eu e as outras pessoas indoutas revelemos tão pouca resistência. Mas se vós outros, os sábios, também vos mostrais vacilantes, isso é que é terrível para todos, pois nem com nos aproximarmos de vós poremos remate a nossas divagações" (376c, grifos nossos).

Chega ao fim o Hipias Menor. Se, em nosso recorte analítico do texto, a ênfase recaiu mais sobre as falas judicativas do que sobre pormenores da argumentação, isto se deve à nossa 
constatação de que as manifestações da ironia socrática são neste diálogo extrínsecas à argumentação no sentido estrito ${ }^{27}$. Por outro lado, se não levássemos em conta o contexto argumentativo, seria difícil distinguir, nas falas de Sócrates, modéstia e elogios irônicos de modéstia e elogios não-irônicos. Fica definido assim o estatuto da argumentação dos personagens do diálogo em nossa análise: fundamental para a aferição da ironia, a argumentação, no entanto, não é o lugar em que aquela pode ser encontrada, cabendo à análise distingui-las ${ }^{28}$.

Páginas atrás, lembrávamos diálogos em que os procedimentos metodológicos de Sócrates estavam fortes mas desacompanhados da ironia (Cármides, Lísis e Filebo). Na análise do Hípias Menor tentamos mostrar como, mesmo quando os procedimentos metodológicos aparecem conjugados com uma forte ironia (ou até auxiliados por ela), esta continua inessencial e extrínseca àqueles. Examinemos então outro diálogo em que os procedimentos metodológicos (refutação, indução, maiêutica, definição) estão todos presentes e convivem com uma ironia salientada por vários autores $^{29}$. Estamos nos referindo ao Hípias Maior, escolhido porque nele a ironia nos parece ainda mais autônoma em relação aos procedimentos metodológicos do que no Hípias Menor. O esquema da análise será basicamente o mesmo e estaremos citando novamente a tradução de Carlos Alberto Nunes. Desta vez, daremos um pouco mais de atenção ao percurso argumentativo do diálogo, sem o quê seria difícil entender a postura de Sócrates diante de Hípias ${ }^{30}$. A argumentação dos interlocutores será agora seguida no transcorrer de nossa análise, e não antes dela.

\section{A ironia socrática no Hípias Maior.}

No diálogo Hípias Maior, a ironia socrática endereçada ao sofista nada fica a dever àquela presente no Hípias Menor. Os interlocutores são os mesmos e Sócrates refuta respostas de Hípias várias vezes. Em desacordo com o desempenho dos interlocutores na argumentação, a falsa modéstia de Sócrates e os elogios exagerados a Hípias dão novamente a tônica. Mas o arsenal de recursos irônicos, dos quais Sócrates costumava lançar mão, ganha um elemento novo que merecerá nossa atenção: a invenção de um personagem fictício por Sócrates, com função eminentemente irônica. Vale dizer, neste diálogo platônico Sócrates se nos apresenta, mais do que em qualquer outro, como um autêntico fingidor.

A primeira fala do diálogo já traz um elogio de Sócrates a Hípias, o primeiro de uma série espalhada por todo o diálogo. A primeira fala de Hípias, também sintomática, nos permite entrever o festival de jactância que o diálogo nos reservará. Vejamos este início:

“ S - Oh! O belo e sábio Hípias! Há quanto tempo não vens a Atenas!

H - É que não me dão folga, Sócrates. Cada vez que Élide tem alguma questão para resolver com outra cidade, sou eu sempre o primeiro que ela escolhe como embaixador, por considerar-me o melhor juiz e relator dos assuntos debatidos em todas elas [...].

S - Isso sim, Hípias, é que é ser homem verdadeiramente sábio e perfeito!" (281 a$b$, grifos nossos)

O diálogo prossegue no mesmo tom, com elogios de Sócrates a Hípias, que se jacta de ser mais sábio que os antigos, ganhar mais dinheiro que outros sofistas e memorizar de uma só vez cinqüenta nomes seguidos. Procurando o motivo pelo qual, apesar da excelência indubitável de Hípias, ele nunca havia ganho dinheiro na Lacedemônia, Sócrates chega a dizer ao sofista: "não há o que não saibas" (286a). Findo este momento inicial do diálogo, em que as relações assimétricas de saber/poder/autoridade entre os dois interlocutores ficam claras, Sócrates introduz a questão central do diálogo, "que é o Belo?". Daí em diante, até o fim do diálogo, Sócrates e Hípias 
tentarão, sem sucesso, dar resposta a esta pergunta. $O$ dado notável neste momento, para o qual vale a pena chamar a atenção, é a invenção de um interlocutor fictício, simulação com a qual Sócrates introduz a questão central:

“ S - ... Recentemente, meu caro, alguém me pôs em grande apuro, numa discussão em que eu rejeitava determinadas coisas como feias e elogiava outras por serem belas, havendo me perguntado em tom sarcástico o interlocutor: Qual é o critério, Sócrates, para reconheceres o que é belo e o que é feio? Vejamos, poderás dizer-me o que seja o belo? - Com a ignorância que me é própria, fiquei atrapalhado e não pude encontrar resposta satisfatória. Ao retirar-me da reunião, senti-me irritado e formulei censuras contra mim mesmo, tendo firmado propósito de, na primeira oportunidade, quando encontrasse um dos vossos sábios, ouvi-lo e instruir-me, e depois de bem estudado o assunto, voltar a procurar o meu interlocutor para reiniciarmos nosso debate. E eis que chegaste na hora certa, como já disse. Explica-me com precisão o que é belo e esforçate por me dar resposta tão exata quanto possível, para que eu não me cubra de ridículo com outra derrota. É fora de dúvida que conheces isso muito bem, matéria, aliás, de pequena relevância entre os inúmeros conhecimentos de que dispões.

H - Sim, muito pequena, Sócrates, por Zeus, e carecente de valor" (286c-e, grifos nossos).

Este tal interlocutor, ficaremos sabendo em um momento posterior do diálogo, não é ninguém senão o próprio Sócrates. Ele inventou este homem fictício para franquear suas refutações a Hípias, que acreditou na simulação. Estabelecida a simulação, Sócrates acerta com Hípias o modo de encaminhar a discussão: a Sócrates, caberá imitar o tal homem, colocando-se no lugar dele do melhor jeito que puder e interrogando Hípias como o homem faria; a Hípias, caberá responder como se o próprio homem o interrogasse. Assim, Sócrates se instruiria e prepararia sua argumentação para responder efetivamente ao seu incômodo interlocutor quando o reencontrasse.

Distribuídos os papéis, Sócrates, simulando desempenhar o do outro homem, passa a proceder então como de costume, em busca da essência do belo. Seu encaminhamento da discussão vai despertando, aqui e ali, leves sinais de irritação e impaciência em Hípias. Este começa por dizer que o belo é uma bela jovem, mas Sócrates, em nome do outro, não se satisfaz com esta resposta. Nas suas falas, Sócrates vai entremeando à sua argumentação elogios irônicos às respostas insatisfatórias de Hípias: "Ótimo, Hípias, pelo cão! Respondeste admiravelmente" (287e). A um dado momento, depois de Sócrates sugerir outros objetos belos (égua bela, lira bela, panela bela), o diálogo começa a ficar tenso:

"H - Mas, Sócrates, quem é esse homem? Como terá de ser ignorante, para atreverse a empregar nomes tão vulgares em assunto de tamanha importância?

S - É assim mesmo, Hípias: sem polimento nenhum, grosseirão e só preocupado com a verdade. De qualquer forma, teremos de dar-lhe alguma resposta" (288cd, grifo nosso).

Vale notar que, com esta resposta, Sócrates simula um endosso ao que dissera Hípias, mas lhe dá um tapa de luva, ao mencionar a preocupação com a verdade como característica do homem que o sofista atacara. Os dois primeiros atributos do homem mencionados por Sócrates ("grosseirão" e "sem polimento nenhum") podem ser vistos como desvalorizadores. Mas o terceiro ("e só preocupado com a verdade") é muito enobrecedor, e está claramente fora de contexto. Como levar a sério uma fala que endossa uma crítica com o maior dos elogios? O sentido literal do 
endosso de Sócrates deve ser rejeitado: a fala de Sócrates traz não um endosso à crítica de Hípias, mas uma insinuação de que a preocupação com a verdade não caracteriza o sofista. Hípias parece não ter percebido a insinuação socrática. Um pouco depois, diante da insistência do homem em perguntar o que seja o belo em si, Hípias volta a atacá-lo, dirigindo-se a Sócrates:

"H - Esse sujeito é mais do que inepto, e nada entende das coisas belas. Se lhe respondesses: $\mathrm{O}$ belo, a respeito do qual me interrogas, não é senão o ouro, ele ficaria confuso e não persistiria em contestar-te [...].

S - É que não sabes, Hípias, como o nosso homem é teimoso e difícil de aceitar alguma coisa.

H - Como assim, Sócrates? Se o que se fala é certo, terá de aceitar. Caso contrário, cairá no ridículo.

S - Tenho certeza, amigo, de que não somente ele rejeitará essa resposta, como ainda zombará de mim e me dirá: quanta cegueira!" (289e).

Ora, se o diálogo futuro que Sócrates prevê entre ele próprio e o suposto interlocutor reproduzirá, como foi dito, o diálogo atual com Hípias; se Sócrates responderá ao homem como Hípias lhe respondeu, e se o homem se comportará do modo como Sócrates se comporta ao tentar imitá-lo, então podemos concluir que é Sócrates quem zomba de Hípias no trecho anterior. Mais ainda, num artifício engenhoso, zomba de Hípias como se fosse o outro homem a zombar de Sócrates. Vale dizer, a zombaria efetiva de Sócrates contra Hípias acaba sendo feita sob o disfarce do outro interlocutor e do outro diálogo que Sócrates e Hípias encenam, como se o antecipassem. Hípias não percebe, mas Sócrates está representando mais do que ficara combinado.

Ao longo do diálogo, Sócrates dirigirá magistralmente o teatro em que toma parte junto com Hípias, este quase uma marionete da ironia socrática (representando o papel designado por Sócrates numa encenação cujo verdadeiro sentido lhe escapa). Às voltas com novas dificuldades, Hípias volta a atacar o homem:

“H - Por Héracles! Que homem, Sócrates! Não quererás dizer-me quem é ele?

S - Não o conheces, ainda mesmo que te dissesse como se chama.

H - Porém uma coisa eu sei: que é um tipo ignorante.

S - É um sujeito terrível, Hípias. Mas, de qualquer forma, que lhe responderemos? [...].

$\mathrm{H}-[\ldots]$ Eu não conversaria com um indivíduo que apresentasse perguntas desse tipo.

S - E com toda a razão, amigo; nem fica bem preocupar-se com nomes tão vulgares um indivíduo como tu, de vestes tão bonitas e com esses calçados, e tão conhecido em toda a Hélade por sua sabedoria. Porém nada me impede de ocupar-me com um tipo de tal espécie. Por isso, continua a instruir-me e responde por amor de mim" (290d-291b).

É de se notar agora o modo como nesta passagem, simulando uma certa cumplicidade para com Hípias, Sócrates passa a elogiar nele características mundanas (belas vestes, bons calçados, fama de sábio). Ora, tais características não devem ser vistas como credenciais seguras de sabedoria, e nem sequer formam um conjunto homogêneo e harmonioso com a sabedoria ${ }^{31}$. Se conjugarmos este elogio ambíguo de Sócrates a Hípias com aquela crítica anterior de Sócrates ao homem (este seria "só preocupado com a verdade", como vimos em $288 \mathrm{~d}$ ), o sentido irônico dos juízos de valor de Sócrates ficará mais claro.

Se tais evidências não bastassem, haveria ainda uma incongruência perceptível no curso 
da conversa: Sócrates insiste em elogiar Hípias e suas respostas (291a), mas ao mesmo tempo insiste nas críticas e refutações que o suposto interlocutor lançará contra as respostas de Sócrates. Ora, se as respostas que Sócrates dará ạo interlocutor serão aquelas que ele ouve de Hípias no diálogo atual, como explicar a postura radicalmente distinta de Sócrates e do outro homem diante das mesmas respostas? Se Sócrates as recebe com elogios, por quê prevê que o outro as criticará? Sócrates seria mais benevolente e suave que o outro homem que ele diz imitar? Pouco provável.

Na verdade, Sócrates se vale da oscilação entre os três papéis que desempenha na conversa, a saber: 1) o de Sócrates, conversando com Hípias; 2) o de Sócrates, respondendo ao suposto interlocutor com as mesmas respostas que ouvira de Hípias; 3) o do interlocutor, recusando tais respostas. Este acúmulo de papéis desempenhados por Sócrates na conversa com Hípias permite ao ateniense administrar as ambigüidades e as diferenças de postura na passagem de um a outro, de modo a encurralar o sofista até que este responda satisfatoriamente o que é o belo. Como Hípias não consegue responder, o diálogo chega a um impasse e muda de rumo. $\mathrm{O}$ ponto de inflexão é marcado por uma fala em que Sócrates, no papel do outro homem, critica as respostas que lhe estariam sendo apresentadas por Sócrates (respostas que apenas reproduziam as de Hípias), e se propõe a responder o que é o belo:

"S - [imitando o interlocutor fictício] Ó bem aventurado Sócrates, dirá ele; Tuas respostas são por demais simplórias e muito fáceis de refutar” (293d).

Deste momento até o final do diálogo, o interlocutor fictício, representado por Sócrates, tomará a iniciativa de propor respostas à questão sobre o que é o belo. Ele tentará, sem sucesso, definir o belo como o conveniente (293e), o útil (295c), a capacidade (295e), o bom ou vantajoso (296e), o que proporciona prazer por meio da vista e do ouvido (297e-298a). No percurso, Hípias vai perdendo espaço, praticamente se limitando a dar respostas curtas, assentindo ou não ao que Sócrates propõe. A autoconfiança até então inabalável do sofista começa a dar pequenos sinais de desgaste. $\mathrm{O}$ endosso de Sócrates às falas imodestas de Hípias não parece muito convicto, e revela certa complacência que soa irônica. Tomemos o trecho seguinte:

“S - Babau! Tornou a escapar-nos, Hípias, o conhecimento do que seja o belo [...].

H - É muito certo, Sócrates, por Zeus, e isso me deixa extremamente confuso.

S - De qualquer forma, companheiro, não permitiremos que nos fuja; ainda remanesce a esperança de chegarmos a descobrir o que seja o belo.

H - Sem dúvida, Sócrates; e não será difícil. Tenho certeza de que, se me recolher algum tempo para refletir, apresentar-te-ei uma definição mais exata do que toda exatidão.

S - Não prometas muita coisa, Hípias; bem vês quanto trabalho esse assunto já nos deu; não vá aborrecer-se conosco e fugir para mais longe. Mas estou falando à toa; pois sei muito bem que o encontrarás com facilidade quando ficares só. Mas, pelos deuses, descobre-o na minha presença, ou, no caso de estares de acordo, associa-me a essa pesquisa, como fizeste até agora. Se o encontrarmos, será ótimo; caso contrário, resignar-me-ei com minha sorte, e, uma vez posto de lado, facilmente o encontrarás" (294e-295b, grifos nossos).

Pouco depois, Hípias e Sócrates se deparam com um novo impasse, diante do qual o sofista reitera sua autoconfiança (um pouco mais arranhada), a qual não impede, porém, que Sócrates retome a iniciativa da argumentação:

“ S - De minha parte, Hípias, não sei para onde virar-me; estou desorientado. E tu, tens alguma sugestão a fazer? 
H - Nesse momento, nenhuma; mas, como disse há pouco, se puser-me a refletir, encontrarei algo.

S - Porém, dada a minha sede de saber, acho que não agüento essa demora. [...] Se respondêssemos àquele sujeito impertinente: o belo, caro amigo, é o que nos deleita por meio da vista e do ouvido, não te parece que poríamos fim ao seu atrevimento?"' (297d-298a).

Sócrates havia deixado um pouco de lado a figura do interlocutor fictício, desde o momento em que passou a tentar propor respostas em seu próprio nome. Agora, Sócrates reintroduz a figura do interlocutor e esta volta coincide com o desgaste da segurança de Hípias. Podemos notar tal desgaste num momento em que, aproveitando a oportunidade dada por Hípias, Sócrates insinua ser ele próprio o interlocutor. Diante da insinuação, Hípias controla o ímpeto de atacar o homem, se porta com prudência e muda de assunto:

“S - E as belas ocupações e instituições, Hípias, diremos que são belas por nos agradarem através da vista ou do ouvido, ou serão de natureza diferente?

H - É bem possível que ao nosso homem não ocorresse semelhante distinção.

S - Pelo cão, Hípias! Porém não seria de esperar o mesmo com a pessoa diante da qual eu mais me envergonharia de divagar sem nexo e de imaginar que digo alguma coisa, quando, em verdade, nada digo.

H - Quem é essa pessoa?

S - Sócrates, filho de Sofronisco, que de jeito nenhum me permitiria enunciar superficialmente qualquer proposição, sem a ter examinado a fundo, nem afirmar o que não conheço como se, de fato, conhecesse.

$\mathrm{H}$ - Eu, também, depois do que disseste, me inclino a pensar que o caso das leis é diferente" (298b-c).

A partir desse momento, Sócrates, cada vez mais à vontade e desenvolto, passa a perguntar e responder em seu próprio nome (298c-d), no nome de "outro indivíduo qualquer" (ibid.), e no nome do suposto interlocutor. Ele agora administra todas as perguntas e respostas, bem como distribui as falas para os personagens que lhe convém convocar.

Hípias se limita a dizer "sim" (299c-e), "sem dúvida" (299d), "perfeitamente" (ibid.) e outras respostas do mesmo tipo, até que Sócrates o exorte a responder a um outro indivíduo que o teria perguntado. A questão em causa gera controvérsia, e Hípias ensaia uma retomada da postura inicial de segurança e autoconfiança. Sócrates responde em grande estilo, com ironia:

" $\mathrm{S}$ - Pode muito bem ser isso, Hípias; talvez eu apenas imagine entrever algo que tu declaras não ser possível, quando, em verdade, nada vejo.

H - Não há talvez, Sócrates; é fato estares vendo mal.

S - No entanto, esvoaçam-me ante o espírito muitas imagens do mesmo gênero, em que não confio, por não as perceberes também, visto já teres ganho mais dinheiro com tua sabedoria do que todos os sábios do nosso tempo ${ }^{32}$, enquanto eu nunca obtive um óbolo sequer. Mas ponho-me a refletir, companheiro, se não estás brincando comigo e não me enganas de caso pensado, tantas e tão nítidas são essas imagens.

H - Ninguém, Sócrates, como tu, se acha em condições de saber se eu estou ou não brincando. Bastará dispores-te a explicar o que te surge ao espírito, para te convenceres de que carece absolutamente de consistência" (300c-d).

Nesta passagem, Sócrates desfere dois golpes de ironia em Hípias: 1) realça em Hípias, 
como se o elogiasse, algo de que o sofista se jactara (remuneração alta), fingindo compartilhar com ele a mesma escala de valores, em que o dinheiro é o valor máximo. Além disso, faz da remuneração um critério de autoridade intelectual (quanto maior o dinheiro ganho, mais sábio seria o sábio que o ganhou, e mais respeitáveis seus argumentos numa discussão). Ora, tal critério é invocado no exato momento em que a argumentação de Hípias, seu beneficiário, parece prestes a fraquejar. Se a argumentação de Hípias se mostrasse inválida ali, o critério da remuneração teria de ser descartado e Hípias perderia um de seus maiores trunfos na discussão. 2) sugere que Hípias pode estar simulando (quando na verdade quem simula é ele Sócrates). Ao dizer isso, Sócrates deixa explícito que a simulação faz parte dos comportamentós possíveis numa conversa, e poderia muito bem estar presente naquela conversa. Hípias, depois da sugestão de Sócrates, teria elementos para desconfiar de uma possível simulação de Sócrates, embora não pudesse ter certeza dela. Mas sua resposta evidencia antes impaciência que desconfiança.

A questão que motivou a passagem anterior é a seguinte: pode haver uma qualidade ou essência que pertença a um par de objetos sem pertencer a cada um em particular, ou vice versa? Sócrates sustenta que sim, e Hípias que não. A discussão avança, e seu desdobramento nos reserva ainda ataques de Hípias a Sócrates e respostas irônicas de Sócrates:

"H - Respondeste, Sócrates, com um absurdo maior do que o primeiro. Reflete um pouco [...]. O fato, Sócrates, é que nunca vês as coisas em conjunto, como se dá também com teus interlocutores habituais, porém amputais do todo o belo ou qualquer outra porção do real e o percutis com vossos discursos. Por isso vos escapam grandes trechos da natureza das coisas. [...] Tão carecentes de lógica, de método, de bom senso e de inteligência todos vos mostrais!

$\mathrm{S}$ - Somos assim mesmo, Hípias; como diz o provérbio; Ninguém é o que quer, mas o que pode. Porém lucramos bastante com tuas admoestações. Agora, por exemplo: queres que te mostre até onde ia nossa ingenuidade, antes de nos teres repreendido, com dizer-te o que pensamos a esse respeito? Ou será melhor não falar nada?

H - De antemão, Sócrates, sei o que vais dizer. Conheço muito bem como são as pessoas que se ocupam com discursos. Mas, se encontras prazer nisso, podes falar.

S - Encontro, sim. Nós outros, amigo, éramos tão estúpidos antes de no-lo declarares, a ponto de imaginarmos ao meu e ao teu respeito, que cada um de nós constituía uma unidade, e que isso que cada um de nós era, os dois não podiam ser, por não sermos um, porém dois. Tão grande era nossa ingenuidade. Agora, porém, aprendemos contigo que, se juntos, somos dois, cada um de nós também terá de ser dois; e o inverso: se cada um de nós é um, os dois juntos também seremos um. [...] Convencido agora por ti dessa verdade, daqui não saio. Antes, porém, Hípias, ajuda-me a recordar uma particularidade: eu e tu seremos um, ou tu és dois e eu também sou dois?

H - Que queres dizer, Sócrates?

$\mathrm{S}$ - Isso, precisamente, que acabei de falar. Tenho medo de ser mais claro e irritarte, por pensares que estás com a razão" (300e-302a)

Note-se, na última fala de Sócrates, a consciência muito clara do efeito de suas refutações às falas seguras e autoconfiantes de Hípias. Sócrates explicita ali o que já era perceptível: ele administra suas falas em função do efeito que elas possam produzir em Hípias. Entre o que lhe vem à cabeça e o que ele fala há um cuidadoso processo de seleção e organização com vistas a determinados fins (a saber, a administração da conversa). 
A investigação desembocará em outro impasse, formulado de modo claro e até irritante por Sócrates. Hípias, no auge da exasperação, atacará duramente Sócrates, que encerrará o diálogo com ironia:

“ S - [...] Concluís que o belo é o prazer útil? Parece-me que sim, seria a minha resposta. E a tua?

H - A minha também.

$\mathrm{S}$ - Porém o útil, [o interlocutor fictício] continuará a falar, é o que produz o bem. Mas o produtor e o produto já se nos revelaram como diferentes; e assim nosso discurso volta ao ponto de partida; nem o bem pode ser belo, nem o belo pode ser bom, se cada um deles for algo diferente. Se formos sábios, Hípias, teremos de concordar plenamente com isso, pois não é permitido dissentir de quem diz a verdade.

H - Mas, Sócrates, que pensas de nossa discussão? Como disse há pouco, são aparas e migalhas de argumentos reduzidos a pedacinhos. Belo, porém, e de muito valor é poder alguém dizer bem um ótimo discurso, no tribunal ou no conselho, ou diante de qualquer autoridade pública a que seja dirigida a oração, e a tal ponto persuadi-la que termine por levar dali, não algum prêmio insignificante, senão o maior de todos: a salvação de si próprio, de seus haveres e dos amigos. A isso é que deverias aplicar-te, abandonando essas futilidades, para não passares por tolo chapado, com te ocupares, como agora, com tantas tolices e palavrório vazio.

S - Meu caro Hípias, és realmente bem-aventurado, tanto por saberes em que os homens devem aplicar-se como por te haveres esforçado nesse sentido, conforme o declaraste. Eu, pelo contrário, como parece, caí nas malhas de um destino adverso, que me leva a errar sem pausa e em perpétua incerteza, e quando a vós outros confesso, por serdes sábios, minhas dificuldades, vejome maltratado com expressões rudes, mal acabe de falar. Dizeis-me sempre o que agora mesmo declaraste: que só me ocupo com questões absurdas, mesquinhas e carecentes de valor. [...]. Talvez eu tenha mesmo de passar por tudo isso, nem será de admirar que me seja de alguma utilidade. Uma coisa, pelo menos, Hípias, presumo haver aproveitado em vossa companhia: imaginar que compreendo o significado do provérbio: O belo é difícil" (303e-304e, grifos nossos).

Essa última fala de Sócrates, que encerra a conversa, traz uma suma dos procedimentos irônicos dos quais ele lançou mão ao longo de todo o diálogo: desvalorização de si e elogios exagerados a Hípias em desacordo com a situação, criação de um terceiro personagem e administração dos papéis manipulados.

\section{Reexame da definição de ironia socrática e de seus aspectos metodológico, literário e retórico.}

No Hípias Menor, a ironia socrática poderia ser definida como um modo de proceder de Sócrates, na conversa, que consiste em emitir juízos de valor que se chocam com a situação argumentativa na qual eles aparecem. A diferença entre esta definição específica e aquela outra genérica, proposta no item 2 supra, embora não seja irrelevante, pode ser administrada sem maiores dificuldades, a primeira servindo para corrigir e precisar a segunda.

Talvez não possamos dizer o mesmo no caso da ironia presente no Hípias Maior. A criação do personagem fictício a singulariza, e sua singularidade dificulta o trânsito suave que 
levaria da definição genérica para a definição específica. O Hípias Maior é um exemplo de diálogo para o qual a definição genérica da ironia socrática não tem pertinência. Nele, à semelhança do Hipias Menor, a simulação e o desacordo entre fala e situação estão presentes, mas a criação do personagem fictício ultrapassa a definição genérica e nos força a mudar os parâmetros de abordagem.

Com efeito, nossa análise dos dois Hípias procurou, entre outras coisas, reforçar a idéia de que ironia socrática e método socrático não se identificam. No Hípias Maior, tal como procuramos analisá-lo, isto fica patente: Sócrates poderia refutar as respostas de Hípias em seu próprio nome, sem inventar um personagem fictício. Esta invenção, prescindível do ponto de vista do método socrático, deve ser encarada por outro prisma. Poderíamos vinculá-la às dimensões literária e retórica da ironia socrática? Reexaminemos estas dimensões.

A dimensão literária da ironia, nos termos em que a apontamos no item 3 supra, não nos diz muito acerca da natureza da ironia socrática. Esta teria uma dimensão literária por pertencer a um discurso do gênero literário (o diálogo platônico). O adjetivo "literária", ali, designaria antes uma relação de pertencimento (ironia literária $=$ aquela que aparece no discurso literário) do que a literariedade da ironia. Dessa forma, o reconhecimento da literariedade da ironia socrática dependeria do reconhecimento da literariedade do diálogo platônico. Como conseqüência, a ironia do personagem Sócrates remontaria, em última análise, à ironia do autor Platão ${ }^{33}$. No caso do Hípias Maior, a ironia envolvida na criação do personagem fictício por Sócrates deveria ser creditada a Platão, criador de ambos os personagens.

Um desdobramento possível consistiria em distinguir os níveis ocupados por Platão e Sócrates nos diálogos ${ }^{34}$. Poderíamos ainda buscar em certas categorias da teoria da narrativa e das ciências da linguagem (sujeito da enunciação, sujeito do enunciado, autor implícito, narrador) um refinamento dos instrumentos de análise que aprimorasse a separação das instâncias narrativas dos diálogos em busca da apreensão da ironia literária neles presente. Evitamos, na análise dos dois Hípias, seguir uma tal trilha por temermos que ela levasse ao enfraquecimento da ênfase em Sócrates. A análise tenderia a solicitar a atenção para várias instâncias narrativas, dentre as quais o autor implícito ou o sujeito da enunciação acabariam por preponderar. Ora, não queríamos retirar o foco de Sócrates. Com nossa escolha, talvez tenhamos perdido em refinamento do instrumental analítico, mas ganhamos no exercício da atenção ao objeto que visávamos ${ }^{35}$.

Resta retomar a dimensão retórica da ironia socrática. Para isto, voltemos à definição ampla e abrangente, proposta por Lausberg, da retórica como "um sistema mais ou menos bem elaborado de formas de pensamento e de linguagem, as quais podem servir à finalidade de quem discursa para obter, em determinada situação, o efeito que pretende" (Lausberg,1982,p.75). Vimos no item 3 supra como, a partir de uma tal definição, o aspecto retórico da ironia socrática fica claro. Mas se não ultrapassarmos o nível formal da definição de Lausberg, tal aspecto permanecerá pouco manejável analiticamente. Afinal, se encararmos a retórica como Lausberg, em quais discursos poderíamos negar uma dimensão retórica? Concebida como sistema de formas que serve a fins, a retórica se tornaria praticamente co-natural a todo e qualquer discurso (o filosófico e o literário incluídos), e não estaríamos dizendo grande coisa ao apontarmos o caráter retórico da ironia socrática (seja no Hípias Maior, seja em outro diálogo).

Para nos aproximarmos da especificidade da ironia socrática, e para evitarmos mal-entendidos quando falamos de sua dimensão retórica, é preciso lembrar o efeito ou os fins visados pelo discurso do Sócrates platônico. O fim principal do discurso socrático é o conhecimento verdadeiro - no Hípias Maior, o conhecimento do "belo em si" (288a) -, e não o mero triunfo na discussão ou a mera persuasão como instrumento de pode ${ }^{36}$. Dito isto, a dimensão retórica do discurso socrático pode ser apontada sem que se cometa injustiça. Sua dignidade filosófica não estará sob suspeita. Quanto à ironia socrática, não a desqualificaremos se a considerarmos um procedimento antes retórico que metodológico. Afinal, mesmo sem se identificar com o método filosófico 
nem lhe ser redutível (como procuramos mostrar), ela também faz parte - enquanto elemento do discurso - da atividade filosófica do Sócrates platônico, e concorre para a busca da verdade.

Depois das observações e das ressalvas, temos elementos para redefinir a ironia socrática como um procedimento retórico a serviço da busca da verdade em uma atividade filosófica configurada num discurso literário. Se filosofia, retórica e literatura estão implicadas nesta formulação, é porque cremos que a ironia do Sócrates platônico se situa, de certo modo, no ponto de entroncamento das três. No Hípias Maior, tenderíamos a localizar a invenção do personagem fictício no terreno da retórica e da literatura, mais do que no da filosofia. Mas não devemos esquecer que tal invenção está servindo, em última análise, como instrumento para o conhecimento do "Belo em si". Por paradoxal que pareça, estamos diante de uma mentira que concorre para a busca da verdade. Explicitemos e enfrentemos o paradoxo apontando o lugar da ironia na atividade filosófica do Sócrates platônico.

\section{O lugar da ironia na atividade filosófica do Sócrates platônico: o caso do Hípias Maior.}

O lugar ocupado pela ironia na atividade do Sócrates platônico parece constituir um problema e um desafio para quem tenta analisá-la. Aqui, tentaremos delinear este problema, tal como ele se nos apresentou no Hipias Maior. A circunscrição do campo ao Hípias Maior não significa que o problema esteja ausente de outros diálogos. Apenas se fez necessário estabelecer um recorte que tornasse viável nossa argumentação e não truncasse o raciocínio exposto até aqui.

Os termos da equação problemática são a ironia, a busca da verdade e o ideal de univocidade da linguagem. Os dois últimos, centrais na atividade filosófica do Sócrates platônico configurada no conjunto dos diálogos, estão fortes no Hípias Maior. Com efeito, o comportamento de Sócrates neste diálogo revela três pressupostos: 1) a existência do "belo em si", em virtude do qual todas as coisas podem ser chamadas de belas (288a); 2) a capacidade do homem de conhecer o belo em si; 3) a capacidade do homem de defini-lo através da linguagem. De acordo com os dois primeiros pressupostos, não só existe uma verdade universal (o "belo em si"), como ela pode ser alcançada e conhecida por nós; de acordo com o terceiro pressuposto, tal verdade "cabe" nas palavras. Podemos acrescentar, usando termos que não são de Sócrates, que o conceito universal (como o de "belo em si") implica um uso unívoco das palavras. O "belo em si" não pode ser algo que esta ou aquela pessoa entenda por belo. O conceito de "belo em si" deve ser, por definição, o mesmo para todos os falantes ${ }^{37}$.

No entanto, apesar da busca da verdade e do ideal de univocidade da linguagem, Sócrates ironiza. E sua ironia não é fraca ou negligenciável no Hípias Maior. Na coexistência de ironia, busca da verdade e ideal de univocidade da linguagem reside o problema que tentamos delinear. Afinal, no Hípias Maior a ironia implica numa certa mentira (a invenção do personagem fictício) ${ }^{38}$ e depende de uma certa equivocidade das palavras (o desacordo entre o sentido literal das palavras irônicas de Sócrates e a situação em que elas aparecem nos força a interpretá-las num sentido diferente do literal). Como conciliar os três termos coexistentes?

Podemos enfrentar o paradoxo observando que a ironia só é possível num diálogo como o Hípias Maior porque a verdade e a univocidade das palavras ainda não foram alcançadas (embora estejam, sem dúvida, nos propósitos da posição de Sócrates). Quando a verdade e a univocidade se instalarem, a ironia socrática terá, ipso facto, que ser desalojada ${ }^{39}$. Em outros termos, no Hípias Maior a ironia socrática (embora não seja método) concorre para a busca da verdade e da univocidade da linguagem, mas só pode conviver com elas enquanto virtualidades. Estas duas são um ponto de chegada almejado mas ainda não alcançado. Com isto, o paradoxo se 
dissolve, mas percebemos que a ironia não serviria para enunciar as verdades (seja qual for o estatuto destas) quando Sócrates as alcançasse.

\section{Conclusão: a especificidade da ironia socrática.}

O interesse, a complexidade e a riqueza da ironia socrática tornam-se menos visíveis se negligenciarmos sua especificidade. Atentos a ela, poderemos medir a distância que separa o Sócrates platônico de outros ironistas comprometidos com o ceticismo, o relativismo ou a mera busca de poder ${ }^{40}$.

Ao ironizar, Sócrates não visa reforçar ou aproveitar um triunfo na argumentação, para obter poder ou outros benefícios pessoais. No Hípias Maior, como nos outros diálogos aporéticos, Sócrates não escapa da aporia final. Ele não refuta seu interlocutor para assumir o lugar o sábio nem para proferir a verdade definitiva. Ele está tão enredado quanto seu interlocutor nas dificuldades levantadas no diálogo ${ }^{41}$, ou seja, a aporia não representa um triunfo socrático na discussão. Por isso, nem a argumentação nem a ironia de Sócrates nos permitem ver nele um mero "erista" 42 . Mas tampouco um cético ou um relativista, pois a aporia também não deve ser vista como a relativização da verdade nem como a negação da possibilidade de a conhecermos ${ }^{43}$. A aporia deve ser vista como o ponto a partir do qual a investigação será retomada, num processo cujo fim é a descoberta da verdade ${ }^{44}$.

Em nossos dias, a ironia parece associar-se, tanto na atividade de seus praticantes quanto na reflexão de seus estudiosos, com a desestabilização da verdade e do sentido das palavras, o que lhe conferiria um certo caráter cético e relativista ${ }^{45}$. Cremos não ser possível compreender a ironia do Sócrates platônico utilizando, sem mais, tais referenciais. Apesar da ironia socrática não se identificar plenamente com o método socrático nem a ele se submeter; apesar da ironia socrática implicar numa certa mentira e depender de uma certa equivocidade no uso das palavras, ela parece muito menos solidária a alguma forma de ceticismo ou de relativismo do que à busca da verdade e da univocidade da linguagem (encarnada nos conceitos universais). Com efeito, a atividade socrática não visa relativizar nem a verdade nem o sentido unívoco das palavras, mas aplainar-lhes o caminho e assegurar-lhes a vigência futura. A ironia faz parte desta atividade e não deixa de se inserir neste projeto.

As "falsas verdades" e as palavras vazias dos que se supõem sábios (pensemos em Hípias, por exemplo) não são recusadas por Sócrates por serem verdades e palavras, mas por serem falsas e vazias. Recusando-as, Sócrates prepara o caminho para a descoberta da verdade e para a linguagem unívoca. Daí sua diferença, tanto em relação aos ironistas céticos quanto aos relativistas. Daí a especificidade de sua ironia.

\section{Notas}

1 - Sabemos, em todo caso, que muitos discípulos de Sócrates escreveram diálogos socráticos, dos quais grande parte se perdeu. J. Laborderie observa que "le catalogue des disciples de Socrate auxquels la tradition attribue des dialogues est impressionant" (1978, p.44-45). O catálogo dos Sokratikoi lógoi, acrescenta Magalhães-Vilhena, inclui textos tanto de discípulos quanto de adversários de Sócrates. Nele, comparecem Ésquines, Antístenes, Aristipo, os cínicos, os estóicos acadêmicos, os céticos gregos e romanos, Isócrates, Lísias, Teodeto, Libânio, Polícrates, Aristóxeno e os epicuristas (1984, p.216). Ver ainda, sobre os Sokratikoi lógoi, W. Guthrie (1988, p.318).

2 - Sobre a questão socrática, destaquemos os estudos alentados e criteriosos de Magalhães- 
Vilhena (1952 e 1984). Ver também Jaeger (1989, p.346-355); Guthrie (1988, p.313-360); F. Adorno (1990, p.9-25); Tovar (1953, p.21-51); Reale \& Antiseri (1990, p.85-87).

3 - Os textos efetivamente examinados dos três autores aparecem na bibliografia ao final. Os textos de Aristóteles em que Sócrates é mencionado foram preteridos por não serem textos literários ou ficcionais. De qualquer forma, nos textos aristotélicos que consultamos, há passagens proveitosas para o estudo da ironia socrática na Ética a Nicômaco (IV, 7, 1127a-b) e no Organon (Dos Argumentos Sofísticos, 34, 183a-184b). Ver, sobre a fonte aristotélica de Sócrates, Magalhães-Vilhena (1984, p.255-329); F. Adorno (1990, p.114-115); Guthrie (1988, p.340-344); Tovar (1953, p.40-42). Sobre a definição Aristotélica de Ironia, ver MagalhãesVilhena (1984, p.293-294, 318-319, 322-323), Jean Humbert (1967, p.87), Guthrie (1988, p.423), Gourinat (1986, p.345-348) e Vlastos (1987, p.81).

4 - Kierkegaard afirma peremptoriamente que "não encontramos jamais qualquer vestígio dela [da ironia] no Sócrates de Xenofonte" (1991, p.35). Guthrie, por seu turno, admite que há ironia no Sócrates de Xenofonte (1988, p.421, nota 49). Vlastos também, com ressalvas (1987, p.85-87). Quanto a nós, endossamos uma tendência majoritária, à qual o próprio Vlastos parece filiar-se, de considerar a ironia Socrática muito mais forte em Platão do que em Xenofonte. O Banquete de Xenofonte, se contém passagens jocosas e bem-humoradas, não traz ainda a ironia socrática tal como a encontramos em vários diálogos platônicos; nos Memoráveis podemos encontrar alguma ironia (menos vigorosa do que em Platão) ou algo que se aproxime dela em I, II, 34-37; I, IV, 1; IV, II, 3-5; IV, IV, 6-9.

5 - As páginas em que Kierkegaard, na sua dissertação de 1841, trata da "concepção" (o termo é dele) aristofânica de Sócrates (1991, p.108-126) tendem a reforçar nossa avaliação. Apesar do trecho, em que Kierkegaard examina As Nuvens de Aristófanes, conter muitas referências à ironia, não parece haver sequer uma delas que concirna claramente ao comportamento de Sócrates na peça. Há referências à ironia de Aristófanes contra Sócrates e, por outro lado, à ironia do Sócrates histórico. Esta, enquanto ponto de vista novo e polêmico frente à cultura grega de até então, teria provocado a resposta (também irônica) de Aristófanes (cf. p. 110 111). Sobre a ironia nesta peça de Aristófanes, num outro encaminhamento, ver as observações de J. Humbert (1967, p.87). Em artigo mais recente, Vlastos nega peremptoriamente a presença da ironia socrática em textos de Aristófanes: "What is there in our sources to show that Socrates was really the arch-ironist Cicero and Quintilian thought him? Nothing in Aristophanes" (Vlastos, 1987, p.85).

6 - Aliás, certos estudiosos da ironia têm salientado as dificuldades de conceituá-la univocamente. Lembremos Muecke (1978, p.478), Allemann (1978, p.390-391, 395), Maria de Lourdes Ferraz (1987, p.15-17) e Lélia Parreira Duarte (1991a, p.8; 1991b, p.1-2).

7 - Concebendo a ironia como um modo de proceder nos distanciamos daqueles que a concebem como algo que poderíamos chamar de pré-discursivo (ponto de vista, sentimento, concepção do mundo etc). Entre eles, destacamos Kierkegaard, que considera a ironia socrática como um ponto de vista (1991, p.211-235 e passim). A ironia socrática é tratada como um modo de proceder, ainda que não se use esta expressão, em passagens de Hegel (1955), Gadamer (1994, p.96), Festugière (1934) e F. Adorno (1990). Hegel fala da ironia socrática como "un modo especial de comportarse en el trato de persona a persona" (p. 52), "una manera o un recurso de la conversación, a que se recurre para animarla un poco" (p. 55). Festugière diz que a ironia "est une manière d'interroger" (p. 111). Adorno define a ironia socrática como "uma interpretação negativa do modo de refutar socrático da parte daqueles que Sócrates pôs em embaraço" (p. 75, grifo nosso), "uma atitude bastante séria" (p. 76), um "modo de conduzir o exame" (Ibid.). Há os que oscilam na forma de conceber a ironia socrática, como J. Humbert (1967, p.85-90). Em certas passagens ele trata a ironia como algo pré-discursivo, "une attitude d'esprit (...) qui est sous-jacente à tout dialogue" (p. 85). A formulação mais clara desta concepção aparece no seguinte trecho: "puisque l'ironie est la forme que prend chez Socrate le sentiment de son inscience, elle est logiquement antérieure à tout procédé de dialectique" (p. 90). Em outras passagens, no entanto, J. Humbert parece inverter sua posição, chamando a ironia 
socrática de "façon de procéder" (p. 88).

8 - Cícero disse que Sócrates "avait l'habitude de s'effacer dans une discussion, pour laisser plus d'avantages à ceux qu'il voulait réfuter; c'est pourquoi, accordant volontiers ce qu'il ne pensait nullement, il aimait à se servir de cet artifice que les Grecs nommènt eironeia". Premieres Académiques, intitulées Lucullus. Trad. M.A. Lorquet. Livre second, V. In: Cicéron. Oeuvres Complètes, tome troisieme. Paris, J.J. Dubochet et Compagne éditeurs, 1840, p. 440.

9 - Um bom exemplo de definição restritiva da ironia socrática é aquela corrente na Grécia e freqüente nos verbetes de dicionários: "ação de interrogar simulando ignorância". Esta definição restringe a ironia à interrogação (ver a crítica de Humbert, 1967, p.89-90), como se proposições afirmativas não contivessem ironia, e à ignorância simulada, como se, por exemplo, um elogio sem modéstia a outrem não pudesse ser irônico. Ora, à luz das evidências textuais que a leitura dos Diálogos nos proporciona, tal restrição parece inválida.

10 - No âmbito dos estudos literários sobre a ironia, Henri Morier (1961, p.219) e Maria de Lourdes Ferraz $(1987$, p.18) também identificam ironia socrática com método socrático.

11 - Poderíamos aumentar a lista: numa passagem em que Henrique de Lima Vaz se refere aos "três momentos do método socrático, a ironia, a indução e a maiêutica" (Antropologia Filosófica I. São Paulo, Loyola, 1991, p. 35), percebemos que a ironia ocupa o lugar normalmente reservado à refutação. Se o autor, municiado de erudição e rigor incomuns, menciona não a refutação mas a ironia como momento inicial do método socrático, podemos supor que as duas estejam sendo identificadas.

12 - A discussão sobre as relações entre retórica e filosofia tem relevo nos diálogos platônicos Górgias e Fedro. Grosso modo, a posição de Sócrates (que, não esqueçamos, demonstrava uma grande capacidade discursiva) tende a opor as duas e a desvalorizar a retórica. De qualquer forma, esta questão mereceria uma abordagem menos sumária do que a que pudemos apresentar em nosso texto. Sobre ela, cf. Gadamer (1994, p. 90-101), Laborderie (1978, p. 185-188, 271-276, 531-537) e Manon (1992, p. 32-42).

13 - Ao lado da magistral primeira parte ("Le dialogue platonicien: histoire et controverses", p. 11-68) do livro de Laborderie (1978), merecem ser lembradas ainda, sobre o diálogo platônico enquanto gênero literário, páginas de Magalhães-Vilhena (1952, p. 58-96; p. 349-381). Ver também Guthrie (1988, p. 318-320), Koyré (1988, p. 12-14) e Bruna (1968, p. 83-93), os últimos encarando os diálogos platônicos como obras dramáticas.

14 - Para distinguirmos ironia de método no Sócrates platônico, aproveitamos, a nosso modo, observações de Friedlander (1989, p. 146), Schaerer (1938, p. 55; 1941, p. 206-207), Guardini (1956, p. 23-24), Brun (1984, 115), Salgado (1987, p. 364) e até dos próprios Reale \& Antiseri (1990, p. 97-98). Nosso argumento - e o que nele houver de arriscado - são, no entanto, de nossa responsabilidade.

15 - Os três diálogos têm em comum a ausência de interlocutores jactanciosos. Daí Sócrates não ironizar seus interlocutores, mesmo quando os refuta. A refutação socrática, bem como os percalços da argumentação, prescindem quase completamente, nos três diálogos, da ironia.

16 - Veremos esta questão, não raro, se sobrepor à questão da ironia socrática. Guthrie discute, sintomaticamente, a ironia socrática em uma seção dedicada à ignorância de Sócrates (1988, p. 420-426); Michel Gourinat (1986) e Alfonso Gómez-Lobo (1993) publicaram sobre a ironia socrática ótimos artigos inteiramente estruturados em torno da questão da ignorância socrática. Em seu artigo, Gourinat diz que "l'affirmation de sa propre ignorance (...) est le centre même de l'ironie de Socrate" (1986, p. 351). No seu, Gómez-Lobo identifica logo na primeira frase a ironia socrática como "el hábito de Sócrates de confesar su ignorancia" (1993, p. 189).

17 - Em nossa substituição, endossamos o argumento usado por Beda Allemann ao definir a ironia como um modo de dizer o contrário do que realmente se diz: "si je m'écarte ici quelque peu de la terminologie habituelle en replaçant la notion de 'ce qu'on pense vraiment' par celle de 'ce qu'on dit vraiment', c'est uniquement pour éviter l'evasion vers une dimension 'mentale', 
située 'derriere' ce qui est, et qui échapperait à tout contrôle" (1978, p. 396, grifo nosso). O problema apontado por Alleman se agravaria no caso da ironia socrática, pois o "pensamento" de Sócrates escaparia ainda mais ao nosso controle.

18 - Este argumento, com ligeiras variações, é o de Hegel (1955, p. 53), Zeller (1955, p.127), Brochard (1926, p. 37-38), T, Gomperz (1952, p. 63), Festugière (1934, p. 111-113), Robledo (1966, p. 83-85), Jean Humbert (1967, p. 86), Guthrie (1988, p. 424) e Gourinat (1986, p. 348, 352252).

19 - Simeterre (1948, p. 51-53), Gourinat (1986) e Vlastos (1987) são exceções a esta tendência geral. Mesmo que breve, seu exame d passagens dos diálogos platônicos (a cuja letra e sentido se mostram atentos) procura atentar para o contexto discursivo em que aparecem, o que sempre fazem ou outros autores mencionados por nós. Ao cobrarmos dos comentadores maior atenção aos contextos discursivos particulares em que aparecem as falas de Sócrates, endossamos também a crítica muito acertada de Gomez-Lobo ao que lhe parece "el error metodológico más frecuente en las discussiones de la ironía socrática. Dicho error radica en que se supone que hay que dar una interpretación uniforme de todos los pasajes en que Sócrates niega poseer conocimientos. Lo que sugiro es que examinemos, uno a uno, los dominios dentro de los cuales Sócrates niega tener competencia" (Gomez-Lobo, 1993, p. 193).

20 - Sobre a importância (consensualmente reconhecida) do contexto para a aferição da ironia, ver, entre outros, Lausberg (1982, p. 164), Morier (1981, p. 578 e 598), Muecke (1978, p. 491 492), Díaz-Migoyo (1980, p. 57-59) e Salvador (1987-88, p. 205 e 211).

21 - Privilegiamos os diálogos aporéticos por concordarmos com Friedlander quando ele diz que "particularmente fuerte se extiende la ironía al final de aquellos diálogos terminados en aporía" (1989, p. 143).

22 - Aqui não estamos distantes daquilo que Henri Morier chamou de "progression vers l'évidence", em que "l'auteur peut ménager une gradation (...) dans l'ordre de l'évidence, l'intention [ironique] appairaissant de plus en plus claire. C'est une ironie qui se démasque, un striptease de la vérité" (Morier, 1981, p. 599).

23 - Os diálogos platônicos nos quais o contraste entre a modéstia socrática e a jactância de seus interlocutores parece mais claro são, a nosso ver, os seguintes: Hípias Maior, Hípias Menor, Éntifron, República (livro 1), Entidemo, com ressalvas, poderíamos lembrar ainda Górgias, Protágoras e talvez Íon. Cabe acrescentar que vários autores enfatizam tal contraste quando discutem a ironia socrática. René Schaerer propõe estabelecer "comme règles générales que l'ironie s'extériorise dans la mesure où augmente l'écart qui sépare les deux adversaires; et que cet écart est d'autant plus grand que l'interlocuteur de Socrate se fait plus d'illusion sur son propre savoir. [...] Il atteint son maximum quand le dialecticien s'oppose à des encyclopédistes omniscients comme Hippias, des théoriciens impulsifs ou provoquants comme Thrasymaque, Polos, Calliclès, ou des charlatans bavards comme Euthydème ou Dionysodore. Ansi la dualité dialetique s'explicite en ironie à mesure que l'ignorance de Socrate se heurte à des prétentions plus grands et plus aveugles" (Schaerer, 1941, p. 202-203). Lembramos ainda J. Brun (1984, p. 116-128), Tovar (1953, p. 215-248), Robledo (1966, p. 85), Reale \& Antiseri (1990, p. 97-98), F. Adorno (1990, p. 74-77), F, Châtelet (1981, p. 77-87) e Manon (1992, p. 23-27).

24 - Cf. Raymond Simeterre, 1948, p. 52; Simeterre é quem mais enfatiza a ironia socrática no Hipias Menor (cf. p. 51-53), E. Chambry (1947, p. 29-32) e Maurice Croiset (1953, p. 21-25), por sua vez, minimizam não só o valor filosófico deste diálogo, como também a presença, nele, de ironia socrática. No entanto, aposição do Chambry e Croiset não chega a desencorajar nossa escolha do Hípias Menor como objeto de análise da ironia. A nosso ver, ele possui muitas características irônicas (contraste entre modéstia socrática e jactância de Hípias, presença da aporia final, excesso de elogios de Sócrates a Hípias, desacordo entre argumentação e juízos de valor). Esperamos que nossa análise convença também nosso leitor.

25 - Sobre a dimensão argumentativa do Hípias Menor, merece destaque um capítulo, do qual nossa análise é devedora, em que José Cavalcante de Souza acompanha com atenção o 
percurso do diálogo (1969, p.39-50); ver também Simeterre (1948, p.46-50) e Chambry (1947, p.29-30).

26 - Poderíamos invocar, a respeito desta passagem, a noção de "ironie ouverte", tal como formulada por Henri Morier: "C'est l'ironie indubitable, celle qui est éclaircie soit par le contexte soit par la situation, et qui se veut d'autant plus évidente qu'elle doit blesser davantage. Certains l'appellent sarcasme" (1981, p.598). Na exposição de Morier, a ironia aberta corresponde ao último grau de evidência da ironia. (cf. p. 595-598).

27 - Neste sentido, tendemos a discordar frontalmente da definição de Liddel \& Scott, segundo a qual a ironia seria "a mode of argument used by Socrates against the Sophists" (1966, p.491).

28 - Podemos conceder, para nuançar ainda mais nossa posição, que a ironia, apesar de ser um elemento externo, possa auxiliar o primeiro momento do método socrático (a refutação), como aliás ocorre em vários diálogos platônicos de juventude (cf. Schaerer, 1941, p. 198). Assim como a refutação potencializa os efeitos de ironia, a ironia também potencializa os efeitos da refutação. Em alguém refutado com ironia, cala mais fundo a lição: "Seja mais modesto, não saia por aí se vangloriando daquilo que julga saber". Como diz Sócrates numa passagem muito citada do diálogo Sofista (230b-e), a refutação purifica a alma das opiniões orgulhosas e frágeis, lhe dá a exata dimensão de si mesma e a prepara para alcançar a verdade. Nos termos de Sócrates, podemos dizer que a refutação aumenta o seu poder de purificação quando acompanhada de ironia. Não concedemos, no entanto, que esta lhe seja necessária ou constitutiva.

29 - Chambry salienta a ironia no Hípias Maior dizendo que, entre os primeiros diálogos de Platão, "ces petits chefs-d'oeuvre d'ironie, [...] l' Hippias Majeur figure comme le plus mordant et le plus amusant de tous" (1947, p.390); Maurice Croiset (1953, p.21-25) se refere várias vezes à ironia socrática presente no Hípias Maior; Brun, observando que a ironia socrática combate a falsa seriedade dos pretensos sábios, exemplifica com um trecho do Hípias Maior (1984, p.124); até mesmo Cavalcante de Souza, apesar de mais preocupado com a argumentação dos personagens do que com a ironia, acaba se referindo a esta em seu capítulo sobre o Hípias Maior (cf. 1969, p.54-55, 66).

30 - Sobre a dimensão argumentativa do Hípias Maior, são de grande valia algumas páginas de Cavalcante de Souza (1969, p.51-67) e de García Bacca (1945, p.I-XXXVIII). Nossa análise do Hípias Maior deve muito ao acompanhamento cuidadoso do percurso do diálogo levado a cabo por Cavalcante de Souza. García Bacca, por sua vez, aponta os desdobramentos que a posição de Hípias em relação à questão do belo poderia suscitar (mas que não ocorreram ao personagem Hípias no diálogo). A posição de Hípias, quando não interpretada platonicamente, seria mais válida que a de Sócrates em vários aspectos explicitados por Garcia Bacca. Apesar de mais enfático na tentativa de recuperar o valor da posição de Hípias, um texto de Mário Guerreiro (1989, p.59-75) converge com o de García Bacca. Quanto a nós, sem negarmos o interesse desta linha de interpretação do Hípias Maior que procura revalorizar a posição do sofista, preferimos partir de um dado patente no diálogo: a incapacidade de Hípias de demonstrar a validade das suas definições do belo. Não sendo nosso propósito realizar um exame filosófico das definições do belo propostas no Hípias Maior, aquele dado nos pareceu suficiente para caracterizar o malogro argumentativo de Hípias no diálogo com Sócrates. Sobre a dimensão argumentativa do Hípias Maior, ver ainda Chambry (1947, p.383-386).

31 - O elogio de tais características mundanas (belas vestes, bons calçados, fama de sábio) tem precisamente o sentido que Henri Morier (1981, p.584-585) vê no "faux éloge ironique": tratase de um elogio restritivo que, circunscrevendo as virtudes a um campo restrito, nomeia por omissão (na expressão de Morier) as virtudes desejáveis que faltam ao elogiado. Em um tal elogio, a ausência é mais significativa que a presença. No trecho em questão do Hípias Maior, ao limitar seu elogio a Hípias às características mais exteriores e mundanas, Sócrates deixa implícitas (nomeia por omissão) características muito mais importantes, das quais Hípias carece. Talvez a maior delas, no caso de um verdadeiro sábio, fosse a preocupação com a 
verdade, justamente aquela com a qual Sócrates fingiu atacar o homem que Hípias criticara (cf. 288d).

32 - Trata-se de novo, precisamente, daquilo que Morier chamou de "faux éloge ironique" (1981, p.584-585). Ver a nota anterior.

33 - Encontramos um exemplo desta abordagem em Rowe (1987), quando ele apresenta a ironia de Sócrtes num trecho do Fedro de Platão como "a type of irony in Plato which no one misses entirely, namely what is normally labelled as 'Socratic' irony [...]. This sort of irony - which Plato's Socrates in fact employs as much when he is talking about other people as when he is talking to them - is itself also Platonic, in so far as the character who employs it is under Plato's control" (Rowe, 1987, p.88-89).

34 - É exatamente isto o que fazem Laborderie (1978), na quinta parte de seu livro, e Friedlander (1989, p.146-150, 151-154). Encontramos também a distinção (ou um convite a ela) entre ironia socrática e ironia platônica em Festugière (1934, p.111-113), Guardini (1956, p.25) e Rowe (1987, p.89 e passim).

35 - Além disso, julgamos que um trabalho que parta de um recorte analítico mais afeito à teoria da narrativa, por exemplo, possa encontrar subsídios em nosso trabalho e recuperar, para seus próprios fins, o que aqui tiver sido demonstrado. Oxalá nosso trabalho não ofereça muita resistência a quem deseje retomar seus eventuais resultados com outras coordenadas analíticas.

36 - Uma discussão mais cuidadosa sobre o estatuto da verdade no Sócrates platônico ultrapassaria os nossos objetivos neste trabalho. Mas não é arbitrária nossa afirmação segundo a qual o fim último visado pelo discurso do Sócrates platônico é o conhecimento da verdade. Sem contar as referências de Sócrates à verdade no texto mesmo dos Diálogos, nossa afirmação tem respaldo em comentadores dentre os quais lembraremos alguns. Nas Vidas e doutrinas dos Filósofos ilustres (II, 22), Diógenes Laércio já se referia a Sócrates dizendo que "seu objetivo não era levar os outros a renunciarem às suas opiniões, e sim chegar à verdade" (1988, p.53). Na mesma direção, Zeller afirmará mais tarde que "en Sócrates, la finalidad última es precisamente el conocimiento de la verdad" (1955, p.161). Salgado (1987) especifica mais o argumento ao observar que "el método socrático es un método para la verdad" (p. 357) e que "Sócrates propone como camino a la verdad el Diálogo" (p. 358). Tais passagens citadas parecem aplicáveis ao Sócrates platônico ainda quando não tenham se referido a ele.

37 - A definição universal, que Aristóteles (Metafísica, XIII, 4, 1078b, 15-35) atribui a Sócrates, é indissociável da univocidade no uso da linguagem. Émile Boutroux observa que, em Sócrates, a ciência trata não do individual ou do acidental, mas do geral, e "le général dont parle Socrate ne se rapporte ni au monde matériel, ni même à un monde intelligible: c'est proprement le fonds commum des discours et des actions des hommes (...) Et comme, lorsque les hommes conversent entre eux avec bonne foi, ils arrivent tôt ou tard à se mettre d'accord sur l'emploi des mots, il faut bien que les idées que ces mots représentent soient identiques dans tous les esprits" (1897, p.44-45). Na mesma direção, Gadamer nota que "toute entente sur une chose suppose que celle-ci soit bien comprise par les deux interlocuteurs comme une seule et même chose. (...) L'enjeu premier de toute investigation dialogique et dialectique est donc le souci de l'unité et de l'identité de l'objet en question" (1994, p.107).

38 - Examinando ocorrências dos termos "eironeía", "eiron", "eironikós" e outros de mesma raiz em textos gregos, Vlastos (1987) defende a seguinte tese: Sócrates teria sido o responsável pela redefinição do sentido destes termos, que com ele (tal como revelariam os diálogos platônicos) estariam perdendo a conotação negativa de "fingimento", "enganação", "mentira", "falsidade", que tinham entre os gregos no século V a.C. e ganhando um sentido positivo que se consagraria mais tarde em Cícero e Quintiliano (1987, p.84). Impulsionando a transformação histórica posterior da "eironeía" dos gregos na "ironia" dos latinos, os diálogos de Platão já não trariam, segundo Vlastos, termos ligados à eironeía associados ao campo semântico do fingimento. Ao ser neles retratado como ironista, Sócrates não apareceria como 
fingidor, enganador ou mentiroso. Vlastos sustenta sua tese examinando passagens do discurso de Alcibíades no Banquete, (1987, p.87-93), e conclui seu artigo propondo a extensão da tese para o conjunto dos diálogos platônicos. Embora careça do amparo histórico e filológico que fortalecem a argumentação do ilustre helenista, nossa análise mais modesta do Hipias Maior (notadamente no que concerne à invenção por Sócrates do personagem fictício) pareceu encontrar neste diálogo um claro contra-exemplo para a tese de Vlastos. Como procuramos mostrar, Sócrates parece de certa forma mentir e fingir ao praticar a ironia no Hípias Maior, ainda que com o objetivo de alcançar a verdade.

39 - Schaerer (1941) dizia coisa semelhante em termos diferentes, ao sugerir que a ironia resulta de um mal-entendido no afrontamento de dois Eus, e que "si ces moi pouvaient communiquer entre eux de façon parfaite, [...] l'ironie n'aurait aucune raison d'être" (Schaerer, 1941, p.183).

40 - Vários autores nos ajudam a distinguir a ironia socrática de outras ironias. Hegel distingue enfaticamente a ironia socrática da interpretação (mais afinada com a filosofia fichteana, segundo Hegel) que dela apresentaram Ast e F. Schlegel (1955, p.54-56). Guardini distingue a ironia socrática da ironia tout court (1956,p.23-24). Jankelevitch (1964) distingue a ironia socrática tanto da ironia dos cínicos (p. 15-16) quanto da ironia romântica (p. 16-19). J. Humbert (1967, p.88-89) distingue a ironia socrática do "sentido mais corrente das formas modernas de ironia" (o laconismo é de $\mathrm{JH}$ ), mas a aproxima da ironia presente "dans la vie de quelques saints [...] comme saint Philippe de Néri" (p. 88). Gourinat (1986) desvincula a ironia socrática da interpretação, conservada pela "tradição dominante" (p. 351), que dela fizeram os inimigos de Sócrates: "C'est qu'il faut être déjà bien philosophe pour pouvoir distinguer, de l'ironie blessante du sophiste et du démagogue, l'amicale ironie socratique" (p. 353). Brun (1984) distingue a ironia socrática "do exercício de um talento satírico ou da expressão do desejo de difamação" (p. 115). Distingue-a também do sarcasmo e da procura do escândalo pelos Cínicos Antístenes, Diógenes e Crates (p. 126-127).

41 - Gadamer salienta que "Socrate en effet ne cherche pas à réduire son interlocuteur au silence pour se présenter implicitement comme homme de science, mais il veut rendre possible une recherche menée en comum" (1994, p.101). Numa direção próxima, Gourinat diz de Sócrates que "son ironie est philosophique, parce que l'ironiste qu'il est ne s'excepte pas de sa propre ironie" (1986, p.352).

42 - Gadamer conclui uma nuançada comparação entre os procedimentos retóricos empregados de um lado por Sócrates e de outro pelos sofistas afirmando que "la pratique socratique du dialogue differe radicalement des techniques éristiques de réfutation" (Gadamer, 1994, p.101).

43 - Gómez-Lobo (1993, p.189-191) aponta a inadequação da interpretação cética da ironia socrática, segundo a qual a confissão socrática de ignorância estaria fundada no reconhecimento, por Sócrates, da impossibilidade de se conhecer as excelência morais que vemo-lo tentar definir a cada diálogo. Embora Gómez-Lobo se refira apenas a uma versão antiga desta interpretação (atribuída a Arcesilao), cremos que outras versões da interpretação cética que sustentem tal reconhecimento sejam tão inaceitáveis quanto aquela rechaçada por Gomez-Lobo.

44 - Julgamos que a compreensão do sentido da aporia nos diálogos fica prejudicada nesta passagem, freqüientemente citada, de Kierkegaard: "a gente pode perguntar com a intenção de receber uma resposta que contém a satisfação desejada de modo que quanto mais se pergunta tanto mais a resposta se torna profunda e cheia de significação; ou se pode perguntar não no interesse da resposta, mas para, através da pergunta, exaurir o conteúdo aparente, deixando assim atrás de si um vazio. O primeiro método pressupõe naturalmente que há uma plenitude, e o segundo, que há uma vacuidade; o primeiro é o especulativo, o segundo o irônico. Era este último o método que Sócrates praticava freqüentemente" (1991, p.42). No caso da refutação socrática, é certo que o "conteúdo aparente" do discurso do interlocutor se exaure, mas a aporia a que ela conduz não tem como ponto de chegada o "vazio". Sócrates, mesmo nos diálogos que terminam em aporia, jamais busca um vazio (de resto, a purgação de um pensamento falso é antes uma desobstrução do caminho da verdade do que um vazio). Se a conver- 
sa desemboca em uma aporia, esta deve ser vista como ponto de partida para um recomeço posterior da busca da verdade, como bem notou Gadamer (1994, p.100-101). Neste ponto, também a interpretação de Goldschmidt nos parece mais correta que a de Kierkegaard: “... Tel est le sens des 'dialogues aporétiques'qui s'achèvent, au-delà de leur échec, par une exhortation à poursuivre l'enquête. A cet égard, il est vraie que le socratisme est plutôt une méthode et une recherche, mais c'est bien, dans son intention, la recherche d'un dogmatisme jamais atteint" (Goldschmidt, 1970, p.59, grifo nosso). Sobre a interpretação kierkegaardiana (que tendemos de uma maneira geral a não endossar) da ironia socrática, ver Pentzopoulou-Valalas (1979).

45 - Ver, por exemplo, o que Lélia Parreira Duarte chamou de "ironia de segundo grau ou humor" (1991a, p.9-10). A nosso ver, a ironia do Sócrates platônico não parece possuir as características definidoras da "ironia de segundo grau". Por outro lado, a "ironia retórica", tal como caracterizada pela autora no mesmo texto (p.8-9), em contraposição à "ironia de segundo grau", também parece distante da ironia socrática. Em suma, a oposição, nos termos de Lélia, entre "ironia retórica" e "ironia de segundo grau ou humor", talvez não seja uma boa via de acesso à compreensão da ironia do Sócrates platônico.

\section{Referências Bibliográficas}

ADORNO, F. Sócrates. Trad. António J. P. Ribeiro. Lisboa: Edições 70, 1990.

ALLEMANN, Beda. "De l'ironie en tant que principe littéraire". Traduit de l'allemand par JeanPierre Morel. Poétique, 36, nov. 1978, p. 385-398.

ARISTÓFANES. As Nuvens. Trad. e notas de Gilda Maria Reale Starzynski. In: Sócrates (col. Os Pensadores). 4.ed., São Paulo: Nova Cultural, 1987, p. 167-222.

ARISTÓTELES. Metafísica. Livro I, cap. 6; Livro XIII, caps. 4 e 9. Trad. Leonel Vallandro. Porto Alegre: Globo, p. 50-51, 274-277, 289-293.

ARISTÓTELES. Dos Argumentos Sofísticos. Cap. 34. Trad. Leonel Vallandro e Gerd Bornheim. In: Aristóteles, vol. I (col. Os Pensadores). São Paulo: Nova Cultural, 1987, p. 196-197.

ARISTÓTELES. Ética a Nicômaco. Livro III, cap. 8; Livro IV, cap. 7; Livro VI, cap. 13; Livro VII, cap. 2. Trad. Leonel Vallandro e Gerd Bornheim. In: Aristóteles, vol. II (col. Os Pensadores). São Paulo: Nova Cultural, 1987, p. 52-54, 74-75, 112-113, 118-119.

BACCA, J. D. G. "Introduccion filosofica al Hipias Mayor”. In: PLATON. Hipias Mayor y Fedro. Versión directa y notas de J. D. García Bacca. México: UNAM, 1945, p. I-XXXVIII.

BOUTROUX, É. “Socrate, fondateur de la science morale”. In: Études d'Histoire de la Philosophie. Paris: Félix Alcan, 1897, p. 11-93.

BRANDÃO, J. L. "O jogo e o labirinto no Eutidemo" . Revista Filosófica Brasileira, Rio de Janeiro, UFRJ, vol. IV, $\mathrm{n}^{\circ} 3$, dez. 1988, p. 23-48.

BROCHARD, V. “L'oeuvre de Socrate”. In: Études de Philosophie Ancienne et de Philosophie Moderne. Nouvelle éd. Paris: Vrin, 1926, p.34-45.

BRUN, J. Sócrates. Trad. Carlos Pitta. Lisboa: Dom Quixote, 1984, p. 115-128 (Segunda Parte, Cap. III, "A ironia socrática”).

BRUNA, J. "Estrutura dramática num diálogo de Platão". Boletim de estudos clássicos, São 
Paulo, FFLCH-USP, n. VII, 1968, p. 83-93.

CHAMBRY, E. “Notice sur l'Hippias Mineur” e "Notice sur l'Hippias Majeur”. In: PLATON. Oeuvres Completes, tome I. Traduction, notices et notes par E. Chambry. Paris: Garnier, 1947, p. 29-32 e 383-391.

CHÂTELET, F. “O acontecimento Sócrates”. In: CHÂTELET, F. (org.). História da Filosofia Idéias, Doutrinas. Vol. 1 (A Filosofia Pagã). Trad. Maria José de Almeida. 2.ed., Rio de Janeiro: Zahar, 1981, p. 73-87.

CROISET, A. "Hippias Majeur: notice". In: PLATON. Oeuvres Complètes, tome II. Texte établi et traduit par Alfred Croiset. Paris: Belles Lettres, 1949, p. 3-7.

CROISET, M. "Hippias Mineur: notice”. In: PLATON. Oeuvres Completes, tome I. Texte établi et traduit par Maurice Croiset. Paris: Belles Lettres, 1953, p. 21-25.

DÍAZ-MIGOYO, G. "El funcionamento de la ironía". In: MONEGAL, Emir Rodriguez. Humor, ironía, parodia. Caracas / Madrid: Fundamentos, 1980, p. 45-68.

DUARTE, L. P. “Introdução”. Boletim do Centro de Estudos Portugueses da FALE-UFMG, Belo Horizonte, FALE-UFMG, n.13, jun. 1991 a ("Artimanhas da Ironia"), p. 7-11.

DUARTE, L. P. Ironia, humor e literatura ou a questão da ironia romântica. Belo Horizonte, FALE-UFMG, mimeografado, 199lb.

DUCROT, O. "Situação de discurso". In: DUCROT, O. e TODOROV, T. Dicionário das ciências da linguagem. Trad. vários. 6.ed., Lisboa: Dom Quixote, 1982, p. 391-395.

FERRAZ, M. de L. A. A ironia romântica : estudo de um processo comunicativo. Lisboa: Imprensa nacional - Casa da moeda, 1987, p. 15-45.

FESTUGIÈRE, A. J. Socrate. Paris: E. Flammarion, 1934, p.110-131 (chapitre "L'ironiste et la sagefemme").

FRIEDLÄNDER, P. Platon: Verdad del ser y realidad de vida. S/ indicação de tradutor. Madrid: Tecnos, 1989, p.140-154 (Parte I, Cap. VII, "Ironía"). [trad. esp. da 3.ed. de Platon. Band I: Seinswarheit und Lebenswirklichkeit, 1964. 1.ed. 1928].

GADAMER, H.-G. L'Éthique dialectique de Platon. Traduit de l'allemand par F. Vatan et V. von Schenck. Paris: Actes Sud, 1994, p.90-108 (Chapitre I, "La dialectique platonicienne", Section I, "Le dialogue et le mode d'instauration de l'entente", item 5, "Le dialogue socratique"). [Ed. orig.: Platos dialektische Ethik. Hamburg: Felix Meiner Verlag, 1931]

GOLDSCHMIDT, V. “Socrate”. In:Questions Platoniciennes. Paris: Vrin, 1970, p.53-62.

GÓMEZ-LOBO, A. "Ironía Socrática". Revista Latinoamericana de Filosofía, Vol.19, n.2, Primavera 1993, p.189-202.

GOMPERZ, T. Pensadores griegos - historia de la filosofía de la antigüedad, tomo II. Trad. del alemán por Pedro Von Haselberg. Buenos Aires: Guarania, 1952, p. 59-105 (Ed. orig.: Griechische Denker - Eine Geschichte der antiken Philosophie, zweiter Band. Leipzig, 1909)

GOURINAT, M. “Socrate était-il un ironiste ?". Revue de Metaphysique et de Morale, Paris, 91, n.3, juil-sept. 1986, p. 339-353.

GUARDINI, R. La mort de Socrate: Interprétation des dialogues philosophiques Euthyphron, Apologie, Criton, Phédon. Trad. Paul Ricoeur. Paris: Seuil, 1956, p. 9-14, 22-25. 
GUERREIRO, M. A. L. “Apologia de Hípias” . In: ALCOFORADO, Paulo (org.). Anais do I Encontro Fluminense de Filosofia : Filosofia Grega. Niterói: EDUFF, 1989, p. 59-75.

GUTHRIE, W. K. C. Historia de la filosofía griega, vol. III (siglo V. Ilustración). Trad. Joaquin R. Feo. Madrid: Gredos, 1988, p. 309-426.

HEGEL, G. W. F. Lecciones sobre la historia de la filosofía, t. II. Trad. Wenceslao Roces. México: Fondo de Cultura Económica, 1955, p. 51-59 (sección "El método socrático"). [Ed.orig.:1833]

HUMBERT, J. Socrate et les petits socratiques. Paris: P.U.F., 1967, p. 84-96 (Première partie, Chap. IV, "Le dialogue socratique: méthode intellectuelle et action morale").

JAEGER, W. Paidéia - A formação do homem grego. Trad. Artur M. Parreira. 2.ed., São Paulo: Martins Fontes, 1989, p. 343-400 (Livro III, cap. "Sócrates").

JANKÉLÉVITCH, V. L'ironie. Paris: Flammarion, 1964, p. 7-37.

KIERKEGAARD, S.A. O conceito de ironia - constantemente referido a Sócrates. Trad. Álvaro L. M. Valls. Petrópolis: Vozes, 1991, p. 7-235.

KOYRÉ, A. Introdução à leitura de Platão. Trad. Helder Godinho. 3.ed., Lisboa: Presença, 1988, p. 9-16 (cap.1, "O diálogo")

LABORDERIE, J. Le dialogue platonicien de la maturité. Paris: Les Belles Lettres, 1978, p. 1-89, 185-188, 217-223, 266-276, 361-365, 423-442.

LAÊRTIOS, D. “Sócrates". In: Vidas e doutrinas dos filósofos ilustres. Trad., introd. e notas de Mário da Gama Kury. Brasília: UnB, 1988, p. 51-59.

LAUSBERG, H. Elementos de Retórica Literária. Trad., prefácio e aditamentos de R. M. Rosado Fernandes. 3.ed., Lisboa: Fundação Calouste Gulbenkian, 1982.

LIDDELL, H. G. \& SCOTT, R. A Greek-English Lexicon. 9.ed., 6.repr., Oxford: Clarendon Press, 1966, p. 491 ("eiron-eia").

MAGALHÃES-VILHENA, V. de. O problema de Sócrates - o Sócrates histórico e o Sócrates de Platão. Lisboa: Fundação Calouste Gulbenkian, 1984.

MAGALHÃES-VILHENA, V. de. Socrate et la légende platonicienne. Paris: P.U.F., 1952, p. 5896 e 168-203.

MANON, S. Platão. Trad. Flávia Nascimento. São Paulo: Martins Fontes, 1992, p. 11 -55 (cap.II, "Platão e Sócrates").

MONDOLFO, R. O Pensamento Antigo - história da filosofia greco-romana, vol. I. Trad. Lycurgo G. da Motta. 3.ed., São Paulo: Mestre Jou, 1971, p. 135-182 (livro II, cap. I e II).

MORIER, H. Dictionnaire de Poétique et de Rhétorique. 2.ed. augmentée, Paris: P.U.F., 1981, p. 577-617.

MUECKE, D. C. “Analyses de l'ironie”. Traduit de l'anglais par Philippe Hamon. Poétique, 36, nov. 1978, p. 478-494.

PENTZOPOULOU-VALALAS, T. "Kierkegaard et Socrate, ou Socrate vu par Kierkegaard”. Les Études Philosophiques, n.2, avril-juin 1979, p.151-162.

PLATÃo. Apologia de Sócrates. Critão. Laquete. Cármides. Líside. Eutífrone. Ião. Menão. Menéxeno. Eutidemo. Hípias Maior. Trad. Carlos Alberto Nunes. In: Diálogos, vol. I-II. Belém: UFPA (Universidade Federal do Pará), 1980, p. 41-396. 
PLATÃO. Protágoras. Górgias. Trad. Carlos Alberto Nunes. In: Diálogos, vol. III-IV. Belém: UFPA, 1980, p. 41-217.

PLATÃO. Fedro. O primeiro Alcibíades. Trad. C. Alberto Nunes. In: Diálogos, vol. V. Belém: UFPA, 1975, p. 31-99, 197-249.

PLATÃO. Parmênides. Filebo. Trad. C. Alberto Nunes. In: Diálogos, vol. VIII. Belém: UFPA, 1974, p. 19-85 e 103-181.

PLATÃO. Teeteto. Crátilo. Trad. Carlos Alberto Nunes. In: Diálogos, vol. IX. 2. ed., Belém: UFPA, 1988, p. 1-177.

PLATÃO. O segundo Alcibíades. Hípias Menor. Trad. C. Alberto Nunes. In: Diálogos, vol. XI. 2.ed., Belém: UFPA, 1986, p. 121-158.

PLATÃO. O Banquete. Trad. e notas de José Cavalcante de Souza. In: Platão (col. Os Pensadores). 4.ed., São Paulo: Nova Cultural, 1987, p. 1-53.

PLATÃO. Fédon. Sofista. Político. Trad. e notas de Jorge Paleikat e João Cruz Costa. In: Platão (col. Os Pensadores). 4.ed., São Paulo: Nova Cultural, 1987, p. 55-261.

PLATÃO. A República. Trad. J. Guinsburg, introdução e notas de Robert Baccou. São Paulo: Difusão Européia do Livro, 1973, 2 vol.

REALE, G. e ANTISERI, D. História da filosofia, vol. I - Antigüidade e Idade Média. Sem indicação de tradutor. São Paulo: Paulinas, 1990, p. 73-102, 130-131.

ROBLEDO, A. G. Sócrates y el Socratismo. México, Fondo de Cultura Económica, 1966, p. 80-89.

ROWE, C. "Platonic Irony". Nova Tellus - Anuario del Centro de Estudos Clasicos (Mexico), n.5, 1987,p.83-101.

SALGADO, C. L. "El triple nivel del metodo socrático". Revista de Filosofía, México, ano XX, n.60, sept-dic. 1987, p. 356-373.

SALVADOR, V. "Para una pragmatica de la ironia". Eutopías, Minneapolis / Valencia, v.3, n.2-3, otoño 1987 - invierno 1988, p. 203-215.

SCHAERER, R. La question platonicienne: étude sur les rapports de la pensée et de l'expression dans les Dialogues. Neuchâtel: Université de Neuchâtel, 1938, p.51-59 (chapitre IV, section 1, "La sincérité et l'ironie").

SCHAERER, R.. "Le mécanisme de l"ironie dans ses rapports avec la dialectique". Revue de Métaphysique et de Morale, 48e année, n.3, juillet 1941, p.181-209.

SIMETERRE, R. Introduction a l'étude de Platon. Paris: Société d'édition "Les Belles Lettres", 1948, p. 43-57.

SOUZA, J. C. de. Caracterização dos sofistas nos primeiros diálogos platônicos. São Paulo: Faculdade de Filosofia, Ciências e Letras da USP. Boletim n.309, 1969, p. 7-15, 39-67, 141-152.

SPERBER, D. \& WILSON, D. "Les ironies comme mentions". Poétique, 36, nov. 1978, p. 399-412.

TAYLOR, A. E. El pensamiento de Sócrates. Trad. Mateo Hernández Barroso. 3.reimpresión, México: Fondo de Cultura Econômica, 1980, p. 109-144 (Ed. original: Socrates. Londres, 1932)

TOVAR, A. Vida de Sócrates. 2.ed. rev., Madrid: Revista de Occidente, 1953, p. 21-51, 102-103, 175-179, 214-248, 380-382.

VLASTOS, G. "Socratic Irony". Classical Quarterly, vol.37, n.1, 1987, p.79-96.

VOSSIUS, G.-J. "Rhétorique de l'ironie". Traduit du latin et adaptée par Catherine MagnienSimonin. (ed. orig. 1643). Poétique, 36, nov. 1978, p. 495-508.

WOLFF, F. Sócrates. Trad. Franklin Leopoldo e Silva. 2.ed., São Paulo: Brasiliense (col. Encanto Radical), 1982. 
XENOFONTE. Ditos e feitos memoráveis de Sócrates. Trad. (da versão francesa de Eugéne Talbot) Líbero Rangel de Andrade. In: Sócrates (col. Os Pensadores). 4.ed., São Paulo: Nova Cultural, 1987, p. 29-158.

XENOFONTE. Apologia de Sócrates. Trad. Líbero Rangel de Andrade. In: Op. cit., p. 159-165.

XENOFONTE. Banquete. Trad. J. David Garcia Bacca. In: Obras Completas. Mexico: Universidad Nacional Autônoma de Mexico, 1946, p. 355-457.

ZELLER, E. Sócrates y los sofistas. Trad. J. Rovira Armengol. Buenos Aires: Editorial Nova, 1955, p. 95-161 (Ed. original: Die Philosophie der Griechen, II. Tübingen, 1846).

\section{Agradecimentos}

Este artigo resulta de uma pesquisa desenvolvida, com o auxílio de uma Bolsa de Iniciação Científica do CNPQ, junto ao grupo de pesquisa "Ironia e Humor na literatura" (FALE-UFMG), sob a orientação da professora Lélia Parreira Duarte, no período de novembro de 1991 a julho de 1993. Agradeço aqui à Lélia e aos professores da UFMG Jacyntho Lins Brandão, Newton Bignotto, Antônio Orlando Dourado Lopes e Marcelo Pimenta Marques, que discutiram comigo este texto e me ajudaram a aperfeiçoá-lo. As eventuais falhas que o texto possa conter são, no entanto, de minha inteira responsabilidade.

SILVA, Mateus A. L'ironie de Socrate dans les Dialogues de Platon. Classica, São Paulo, 7/8:229$258,1994 / 1995$.

RÉSUMÉ: Nous trouvons fréquemment l'ironie socratique tant dans les études sur l'ironie que dans les études sur Socrate. Cet article prétend vérifier l'incidence inégale de l'ironie socratique dans les sources socratiques les plus importantes; discuter sa définition et quelques uns de ses aspects, à l'aide des interprètes; ébaucher et éprouver une méthode d'analyse des dialogues platoniciens aporétiques qui soit capable de bien la saisir là; finalement, montrer son lieu dans l'activité philosophique du Socrate platonicien, et la spécificité de cet ironiste par rapport à d'autres.

MOTS CLÉS: Socrate, Platon, Ironie, Rhétorique, Méthode Socratique. 